\title{
Binding of Calcium and Magnesium to Cardiac Troponin C
}

Rayani $\mathrm{K}^{1}$, Seffernick $\mathrm{JT}^{2}$, Li YA ${ }^{1}$, Davis $\mathrm{JP}^{3}$, Spuches $\mathrm{AM}^{4}$, Van Petegem $\mathrm{F}^{5}$, Solaro $\mathrm{RJ}^{6}$, Lindert $\mathrm{S}^{2}$, and Tibbits $\mathrm{GF}^{1,7,8}$

${ }^{1}$ Molecular Cardiac Physiology Group, Simon Fraser University, Burnaby, BC V5A 1S6, Canada.

2 Department of Chemistry and Biochemistry, Ohio State University, Columbus, $\mathrm{OH} 43210$, United States.

${ }^{3}$ Department of Physiology and Cell Biology, The Ohio State University, Columbus, $\mathrm{OH}$ 43210, United States.

${ }^{4}$ Department of Chemistry, East Carolina University, 300 Science and Technology, Greenville, NC 27858, United States.

${ }^{5}$ Department of Biochemistry and Molecular Biology, The University of British Columbia, Vancouver, BC V6T 1Z3, Canada.

${ }^{6}$ Department of Physiology and Biophysics and the Center for Cardiovascular Research, College of Medicine, University of Illinois at Chicago, Chicago, IL, United States.

${ }^{7}$ Department of Molecular Biology and Biochemistry, Simon Fraser University, Burnaby, BC V5A 1S6, Canada.

${ }^{8}$ BC Children's Hospital Research Institute, Vancouver, BC V5Z 4H4, Canada.

Running Title: $\mathrm{Ca}$ and $\mathrm{Mg}$ binding to $\mathrm{cTnC}$

Key Words: Contractility, Myofilament, ITC, Calorimetry, MD Simulation, Thermodynamic Integration, Molecular Dynamics 


\section{Abstract}

Cardiac troponin $\mathrm{C}(\mathrm{cTnC})$ is the $\mathrm{Ca}^{2+}$-sensing component of the thin filament. It contains structural sites (III/IV) which bind both $\mathrm{Ca}^{2+}$ and $\mathrm{Mg}^{2+}$, and a regulatory site (II) that has been thought to bind only $\mathrm{Ca}^{2+}$. The latter binding initiates a series of conformational changes that culminate in force production.

We have quantified the interaction between site II and $\mathrm{Ca}^{2+} / \mathrm{Mg}^{2+}$ through Isothermal Titration Calorimetry and Thermodynamic Integration simulations. Direct and competitive binding titrations using wild type and a double mutant that significantly reduces binding to site II demonstrated that physiologically relevant concentrations of both $\mathrm{Ca}^{2+} / \mathrm{Mg}^{2+}$ interact with the same locus. Cytosolic free $\mathrm{Mg}^{2+}(\sim 1 \mathrm{mM})$ could occupy a significant population of available site II, as this concentration of $\mathrm{Mg}^{2+}$ decreased the affinity for $\mathrm{Ca}^{2+} 1.4-$ fold.

Interaction of $\mathrm{Mg}^{2+}$ with site II of cTnC likely has important functional consequences for the heart at baseline and in diseased states which decrease or increase availability of $\mathrm{Mg}^{2+}$ such as secondary hyperparathyroidism or ischemia, respectively. 


\section{Introduction}

Cardiac troponin (cTn) is a heterotrimeric complex that includes components for: $\mathrm{Ca}^{2+}$ binding (troponin $\mathrm{C}-\mathrm{cTnC}$ ), inhibition of contraction (troponin I - cTnl), and tropomyosin binding (troponin TcTnT) (Parmacek and Solaro 2004). $\mathrm{Ca}^{2+}$ binding to site II of cTnC is the precursor to a series of structural perturbations in the thin filament (TF) that culminate in a strong force generating reaction between the actin filament and myosin heads (Kawasaki and van Eerd 1972, Murray and Kay 1972, Potter and Gergely 1975, Filatov, Katrukha et al. 1999, Parmacek and Solaro 2004).

cTnC is a 161-amino acid protein composed of 9 helices $(\mathrm{N}$ and $\mathrm{A}-\mathrm{H})$, which form 4 helix-loophelix binding motifs (sites I-IV). Within these domains, residues in positions $1(+x), 3(+y), 5(+z), 7(-$ y), $9(-x)$, and $12(-z)$ contain oxygen atoms arranged in a pentagonal bipyramid allowing for coordination of metal cations (Figure S1) (Strynadka and James 1989, Yap, Ames et al. 1999, LewitBentley and Rety 2000). Skeletal muscle troponin TnC (sTnC) has 4 functional $\mathrm{Ca}^{2+}$ binding motifs (Seamon, Hartshorne et al. 1977, Ebashi, Nonomura et al. 1980). Cardiac TnC (cTnC) has a similar overall structure but a slightly different primary sequence. The insertion of a valine at residue 28 , along with the substitutions D29L and D31A have rendered site I of cTnC non-receptive to $\mathrm{Ca}^{2+}$ binding (van Eerd and Takahshi 1976, Farah and Reinach 1995).

$\mathrm{Ca}^{2+}$ binding to sites III and IV in the C-domain of cTnC occurs with high affinity $\left(\sim 10^{7} \mathrm{M}^{-1}\right)$ ( 10x higher than the $\mathrm{N}$-domain) and a slow exchange rate ( 100x slower than binding to the $\mathrm{N}$ domain). Given the abundance of contractile filaments throughout cardiomyocytes, cTnC buffers a significant portion of cytosolic $\mathrm{Ca}^{2+}$ (Johnson, Charlton et al. 1979, Johnson, Nakkula et al. 1994, Schober, Huke et al. 2012). At resting free cytosolic $\mathrm{Ca}^{2+}$ concentrations, sites III and IV are usually saturated with $\mathrm{Ca}^{2+}$ (Bers 2000). $\mathrm{Mg}^{2+}$ also binds at sites III and IV, but with lower affinity $\left(\mathrm{K}_{\mathrm{A}} \sim 10^{4} \mathrm{M}^{-1}\right)$ (Potter and Gergely 1975). However, the cytosolic concentration of $\mathrm{Mg}^{2+}$ allows this cation to compete with and reduce the binding of $\mathrm{Ca}^{2+}$ to the "structural" sites (Leavis and Kraft 1978, Robertson, Johnson et al. 1981). The binding of $\mathrm{Ca}^{2+} / \mathrm{Mg}^{2+}$ to sites III and IV alters the structure of TnC and is a prerequisite for thethering to the rest of the TF (Sturtevant 1977, Tikunova and Davis 2004).

The C-domain of cTnC is linked to the $\mathrm{N}$-domain by a linker region composed of a nine turn $\alpha$ helix (Sundaralingam, Bergstrom et al. 1985, Sia, Li et al. 1997). Within the N-domain (N-cTnC), $\mathrm{Ca}^{2+}$ binds the low affinity $\left(\sim 10^{-5} \mathrm{M}\right)$ site II such that this site is only partially occupied at diastolic free $\mathrm{Ca}^{2+}$ concentrations $(\sim 0.1 \mu \mathrm{M})$ (Cheung, Tillotson et al. 1989). The degree of occupancy is significantly higher at systolic free $\mathrm{Ca}^{2+}$ concentrations $(\sim 0.5-1.2 \mu \mathrm{M})$ which follow $\mathrm{Ca}^{2+}$-induced $\mathrm{Ca}^{2+}$-release (Kirschenlohr, Grace et al. 2000). $\mathrm{Ca}^{2+}$ binding to site II provides the free energy to allow exposure of a hydrophobic pocket, which is otherwise less favorable (Gifford, Walsh et al. 2007, Bowman and 
Lindert 2018). Helices B and C (BC domain) move away from helices $N, A$, and D (NAD domain) to expose the hydrophobic cleft, with the short anti-parallel $\beta$-sheet between EF-hands I and II acting as a hinge (Herzberg and James 1985, Slupsky and Sykes 1995, Houdusse, Love et al. 1997). Binding of the "switch peptide" $\mathrm{Tnl}_{147-163}$ to this pocket facilitates exposure of this hydrophobic region (Sia, Li et al. 1997, Spyracopoulos, Li et al. 1997, Li, Spyracopoulos et al. 1999).

A persistant and under-investigated question is the role of cellular $\mathrm{Mg}^{2+}$ in the signaling of activation by cTnC. Of the total cytosolic $\left[\mathrm{Mg}^{2+}\right]_{\mathrm{i}}(\sim 10 \mathrm{mM})$, the majority is bound to cellular components such as ATP with only $\sim 0.5-1.0 \mathrm{mM}$ being freely available in the cytosol (Romani and Scarpa 1992, Dai, Friedman et al. 1997). In conditions with diminished buffering capacity, such as ATP depleted states, the free $\left[\mathrm{Mg}^{2+}\right]$ can increase significantly (Hongo, Konishi et al. 1994, Tessman and Romani 1998) prior to being extruded from the cell (Laires, Monteiro et al. 2004), but it could also compete with $\mathrm{Ca}^{2+}$ for binding to cTnC.

Increase in Mg-ATP in both skeletal and cardiac tissue decreases the $\mathrm{Ca}^{2+}$ sensitivity of skinned fibers (Godt 1974, Best, Donaldson et al. 1977, Godt and Morgan 1984). Further evidence has been obtained through fluorescence-based studies of isolated cTnC (Potter, Robertson et al. 1981, Ogawa 1985, Zot and Potter 1987, Morimoto 1991, Francois, Gerday et al. 1993, She, Dong et al. 1998), the Tn complex (Potter, Robertson et al. 1981, Zot and Potter 1987), and reconstituted fibers (Zot and Potter 1987, Allen, Yates et al. 1992) where $\mathrm{Mg}^{2+}$ appears to decrease $\mathrm{Ca}^{2+}$ sensitivity. In isolated $\mathrm{TnC}$, the $\mathrm{K}_{\mathrm{A}}$ of the low affinity sites (III/IV) for $\mathrm{Ca}^{2+}$ and $\mathrm{Mg}^{2+}$ was measured to be on the order of $10^{6} \mathrm{M}^{-1}$ and $10^{2} \mathrm{M}^{-1}$, respectively (Ogawa 1985).

Interaction of $\mathrm{Ca}^{2+} / \mathrm{Mg}^{2+}$ with sites III/IV results in a large change in enthalpy $(\Delta \mathrm{H})$, in contrast to changes resulting from site I/II binding which are small by comparison. Detection of heat changes associated with the interactions of metal ions and proteins is both challenging and highly technique dependent such that small changes may be deemed negligible (Yamada 1978, Yamada and Kometani 1982, Kometani and Yamada 1983). Experiments used to study this system decades ago were limited by the technology of the time. In contrast, modern Isothermal titration calorimetry (ITC) is a sensitive method to that can be used to define the thermodynamic parameters of binding without the use of labelling methods that could interfer. Modern ITC allows for the study of single binding sites within isolated protein domains and can be used to detect heat changes as small as $0.1 \mu$ cal (Yamada 2003, Wilcox 2008, Grossoehme, Spuches et al. 2010, Sacco, Skowronsky et al. 2012).

We have used ITC to explore the binding of $\mathrm{Mg}^{2+}$ and $\mathrm{Ca}^{2+}$ to site II at the level of $\mathrm{N}$-cTnC and full-length cTnC. Competitive binding to the $\mathrm{N}$-domain and mutations in the site II caused a reduction in apparent affinity, indicating interaction of both cations with the same locus in the protein. In full- 
length $\mathrm{cTnC}, \mathrm{Mg}^{2+}$ competed with and reduced $\mathrm{Ca}^{2+}$ binding to all three sites. These findings further corroborate and expand upon what has been shown by a few labs, but the findings are largely ignored by most; the role of $\mathrm{Mg}^{2+}$ in modulating the $\mathrm{Ca}^{2+}$-sensitivity of force production in cardiomyocytes is one which merits further discussion. 


\section{Methods}

\section{Construct preparation and protein expression}

The TNNC1 gene (Uniprot ID P63316) had previously been cloned into pET21a(+) vector and had a stop codon inserted at residue 90 to create the $\mathrm{N}$-cTnC construct using the Phusion sitedirected mutagenesis protocol (Thermo Scientific). This construct was transformed into the BL21(DE3) expression strain. The D76A/D73A construct was made using site-directed mutagenesis carried out by GenScript (New Jersey, USA). Expression and purification of all constructs were carried out as described previously (Stevens, Rayani et al. 2016, Stevens, Rayani et al. 2017). In brief, $100 \mathrm{~mL}$ of lysogeny broth (LB) was supplemented with $50 \mu \mathrm{g} / \mathrm{mL}$ ampicillin and a glycerol stock stab and grown over-night at a shaking speed of $250 \mathrm{rpm}$ and $37^{\circ} \mathrm{C}$. In the morning, the same conditions were provided to $1 \mathrm{~L}$ cultures that were grown for $\sim 3 \mathrm{hrs}$ to an $\mathrm{OD}_{600}$ of $0.8-1.0$ followed by induction with $\beta$-D-1-thiogalactopyranoside (IPTG). After $3 \mathrm{hrs}$, the cells were harvested by centrifugation and stored at $-80^{\circ} \mathrm{C}$.

\section{Protein purification}

The cell pellet was thawed and suspended in $50 \mathrm{mM}$ Tris-Cl pH 8.0, $5 \mathrm{mM}$ ethylenediaminetetraacetic acid (EDTA) and sonicated on ice, 5 times $30 \mathrm{sec}$ each, with intervals of rest between to avoid overheating. The lysate was centrifuged for 15 mins at 30,000 $\times g$ and the supernatant separated twice to remove all cell debris. The supernatant was applied to a fast-flow Q-Sepharose column pre-equilibrated with the suspension buffer and $1 \mathrm{mM}$ dithiothreitol (DTT). The protein was eluted from the column by applying a $180 \mathrm{~mL}$ ramp gradient to the same buffer supplemented with 0.5 $\mathrm{M} \mathrm{NaCl}$. The gradient was applied using an AKTA FPLC machine that was also used to fractionate the eluted samples. Following analysis by SDS-PAGE, the samples containing N-cTnC were pooled and concentrated using Amicon centrifugal concentrators with a $3 \mathrm{KDa}$ molecular weight cut-off (Millipore).

The full-length protein was purified in the same way, with the addition of a $30 \%$ ammonium sulphate following the sonication step. Centrifugation was then used to remove insoluble components and the supernatant was then dialyzed overnight against $4 \mathrm{~L}$ of column-buffer containing $50 \mathrm{mM}$ Tris$\mathrm{Cl} \mathrm{pH} 8.0$ and $100 \mathrm{mM} \mathrm{NaCl}$.

The concentrated protein was then applied to a HiPrep 26/60 Sephacryl S-100 column (DEAE FF) (GE healthcare) which was equilibrated with the re-suspension buffer supplemented with $100 \mathrm{mM}$ $\mathrm{NaCl}$. SDS-PAGE analysis of the fractions was used to identify and pool those containing cTnC. The protein was stored at $-80^{\circ} \mathrm{C}$ prior to pre-ITC dialysis. 


\section{Dialysis and ITC experiments}

To generate the apo-state protein, troponin $C$ was first dialyzed against $2 \mathrm{~L}$ of $50 \mathrm{mM}$ HEPES $\mathrm{pH}$ 7.2, $150 \mathrm{mM} \mathrm{KCl}, 2 \mathrm{mM}$ EDTA, and $15 \mathrm{mM} \beta$-mercaptoethanol (BME), followed by another dialysis against the same buffer. Each of these dialysis steps was completed at $4^{\circ} \mathrm{C}$ for a minimum of $4 \mathrm{hrs}$. $\mathrm{A}$ third dialysis was performed for a minimum of $16 \mathrm{hrs}$ overnight against $2 \mathrm{~L}$ of $50 \mathrm{mM} \mathrm{HEPES} \mathrm{pH} \mathrm{7.2,}$ $150 \mathrm{mM} \mathrm{KCl}$, and $2 \mathrm{mM}$ EDTA. An extinction coefficient of $1490 \mathrm{M}^{-1} \mathrm{~cm}^{-1}$ and $4595 \mathrm{M}^{-1} \mathrm{~cm}^{-1}$, and a molecular weight of $10.1 \mathrm{kDa}$ and $18.4 \mathrm{KDa}$ were used to determine protein concentration for the $\mathrm{N}$ cTnC and full length cTnC constructs, respectively, by $280 \mathrm{~nm}$ UV-vis spectroscopy using a NanoDrop 2000 spectrophotometer (Thermo Scientific). The final dialysis buffer was used to dilute the protein samples to a final concentration of $200 \mu \mathrm{M}$ for the $\mathrm{N}$-terminal construct and $150 \mu \mathrm{M}$ for full length cTnC as described previously (Stevens, Rayani et al. 2017).

\section{Experimental Protocols}

\section{Full-length cTnC}

Standard $1.0 \mathrm{M} \mathrm{CaCl}_{2}$ and $\mathrm{MgCl}_{2}$ stock solutions (Sigma, USA) were serially diluted in the final dialysis buffer to produce $6 \mathrm{mM} \mathrm{Ca}^{2+}$ and $40 \mathrm{mM} \mathrm{Mg}^{2+}$ for the full length cTnC titrations. $6 \mathrm{mM} \mathrm{Ca}^{2+}$ was titrated into $100 \mu \mathrm{M}$ apo-state full-length human cTnC as the baseline condition. The data were fit with a two sets-of-binding-sites model. The same amount of protein was diluted in the ITC buffer and used for all subsequent conditions that were fit with the same model. Supra-physiological concentrations $\mathrm{Ca}^{2+}$ were selected for the pre-incubation experiments and justified as the goals of these experiments were not violated. The goals of these experiements were to explore possible competition between $\mathrm{Ca}^{2+}$ and $\mathrm{Mg}^{2+}$ in binding to $\mathrm{cTnC}$ and $\mathrm{N}-\mathrm{cTnC}$. Higher concentrations could thus be used to observe clearer results. Also, the amounts of $\mathrm{cTnC}$ and $\mathrm{N}-\mathrm{cTnC}$ are above what is available in the cell and the affinity of their binding sites is lowered as they exist in isolation in these experiments ie. their affinities would be elevated by the presence of other cTn complex proteins. The concentrations of $\mathrm{Mg}^{2+}$ pre-incubated $(1$ and $3 \mathrm{mM}$ ) is not far beyond what would be expected in normal cellular conditions.

\section{$N$-terminal cTnC}

The same standards were used to produce $4 \mathrm{mM} \mathrm{Ca}^{2+}$ and $20 \mathrm{mM} \mathrm{Mg}^{2+}$ titrants for the $\mathrm{N}-\mathrm{cTnC}$ experiments. $4 \mathrm{mM} \mathrm{Ca}^{2+}$ was titrated into $200 \mu \mathrm{M}$ apo-state $\mathrm{N}-\mathrm{cTnC}$ as the baseline condition with subsequent titrations using the same amount of protein. The isotherms were all fit with a single binding site model. 


\section{Titrations}

The ITC experiments were carried out in a MicroCal ITC200 instrument (Malvern, UK). Repeat titrations were used to ensure reproducibility. The sample cell was set at $25^{\circ} \mathrm{C}, 200 \mu \mathrm{L}$ of the protein was loaded and the experiment was carried out at the same temperature. For the N-terminal constructs, 19 injections of the titrant were used with the first being a dummy injection of $0.8 \mu \mathrm{L}$ and the subsequent 18 injections, $2 \mu \mathrm{L}$ each. For the full-length constructs, the same volume of sample was titrated with a dummy injection of $0.5 \mu \mathrm{L}$ and 38 injections of $1 \mu \mathrm{L}$. The time interval between injections was $120 \mathrm{sec}$ and stirring speed was set at 1,000 rpm throughout each experiment.

\section{Analysis of results}

Titration data obtained from ITC were fit using Origin 8.0 (OriginLab, Northampton, MA) to calculate the thermodynamic parameters using a least-squares algorithm by the software. In this method, if multiple ligands were simultaneously present in the reaction mixture, an "apparent affinity" was determined for the injected titrant. Origin also allows for fitting of more complex models of interactions which were utilized in the case of multiple binding sites for the full length cTnC experiments.

When fitting the data for the $\mathrm{N}-\mathrm{cTnC}$ constructs (apart from the $\mathrm{Ca}^{2+}$ into Apo-state $\mathrm{N}$-cTnC condition), the $\mathrm{N}$ associated with each interaction was necessarily constrained to equal 1.00 to facilitate curve fitting without altering protein concentration. The baseline condition was repeated daily to monitor fluctuations in concentration of properly folded and functional protein.

Protein concentration plays a large role in determination of affinity. The concentration of the titrant may be affected by pipetting errors, albeit this effect is normally minimal. The ratio of the ligand to titrant in the single binding site condition (as given by the stoichiometry $-n$ ) is a measure of the functional moles of protein and was approximately 1.00 in all the N-cTnC titrations. Given the method of concentration determination, the number of binding sites, cooperativity, and the variable binding strength of each titrants, the $\mathrm{N}$ cannot be used in the same way for the full-length $\mathrm{cTnC}$ experiments. Therefore, the values presented can be compared between conditions, but care should be taken when comparing these to other systems. Ease of manipulation of the $\mathrm{N}-\mathrm{cTnC} / \mathrm{cTnC}$ system contrasts with those that include the cTn/TF. Thus, the binding parameters measured here may not translate in absolute term when cTnC is incorporated into a more complex system. 


\section{Thermodynamic Integration (TI)}

Starting from the representative model of PDB:1AP4 (Spyracopoulos, Li et al. 1997), that contains $\mathrm{N}$-cTnC with a single $\mathrm{Ca}^{2+}$ ion bound, the system was solvated with a $12 \AA$ padded TIP3P water box and neutralized with $\mathrm{Na}^{+}$in Amber16 (D.A. Case, R.M. Betz et al. 2016). The system was also prepared similarly for only the $\mathrm{Ca}^{2+}$ ion in a $12 \AA$ padded TIP3P water box. The alchemical thermodynamic cycle used for ligand binding was described in detail previously (Leelananda and Lindert 2016). In short, TI was performed using the following three steps for $\mathrm{Ca}^{2+}$ in protein: turn on restraints, turn off charge, and turn off van der Waals forces. The specific distance restraints used in all systems can be found in Table S1. Additionally, TI was performed for the following two steps for $\mathrm{Ca}^{2+}$ in water: turn off charge and turn off van der Waals forces. Each step of the thermodynamic cycle was performed with the coupling parameter $(\lambda)$ ranging from 0.0-1.0 in increments of 0.1. For each simulation, the system was minimized (2000 cycles) and heated ( $0.5 \mathrm{~ns})$ before the 5 ns production run at $300 \mathrm{~K}$ using the ff14SB force field (Maier, Martinez et al. 2015). These calculations were also performed on the D67A/D73A mutated system. The mutations were imposed on the 1AP4 representative model using PyMOL (L DeLano 2002).

For the calculation of $\mathrm{Mg}^{2+}$ binding affinity, $\mathrm{Ca}^{2+}$ was replaced with $\mathrm{Mg}^{2+}$ in the $1 \mathrm{AP} 4$ representative model since no $\mathrm{Mg}^{2+}$-bound $\mathrm{N}-\mathrm{cTnC}$ structure was available in the protein databank. In order to generate more accurate restraints and starting coordinates for the TI calculations, a minimization was performed on the structure in Amber (2000 cycles). Following the minimization, $\mathrm{TI}$ simulations were run similarly as for $\mathrm{Ca}^{2+}$. However, due to previously documented errors in the

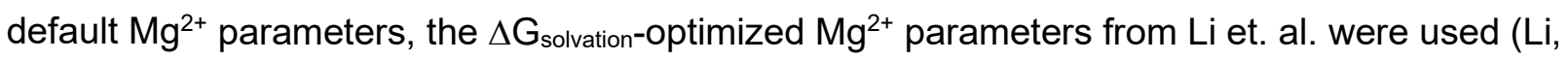
Roberts et al. 2013, Panteva, Giambasu et al. 2015). These calculations were also performed on the D67A/D73A mutated system.

To calculate absolute binding affinities for the ions, the change in free energy $(\Delta \mathrm{G})$ was calculated for each step in the thermodynamic cycle by integrating the potential energy with respect to the coupling parameter, $\lambda$ (Shirts, Mobley, et al. 2010). Two corrections were made to these calculated $\Delta G$ values. The first correction was necessary due to the introduction of the distance restraints (as described in Boresch et al.) which quantified the free energy cost of restraining the ion to the binding site (Boresch, Tettinger et al. 2003). The second correction was performed to correct the charged system (as described in Rocklin et al.) to revise the free energy for the fact that the system is charged during the disappearance of the charged ions (Rocklin, Mobley et al. 2013). The overall $\Delta \mathrm{G}$ of binding was the change in free energy between the ions in complex with the protein (ion in protein steps 1,2 , 
bioRxiv preprint doi: https://doi.org/10.1101/2020.06.14.150854; this version posted June 15, 2020. The copyright holder for this preprint (which was not certified by peer review) is the author/funder. All rights reserved. No reuse allowed without permission.

and 3) and the ions in water (ion in water steps 1 and 2). For each system, 5 independent runs were performed, and results were averaged. 


\section{Results}

\section{N-terminal cTnC}
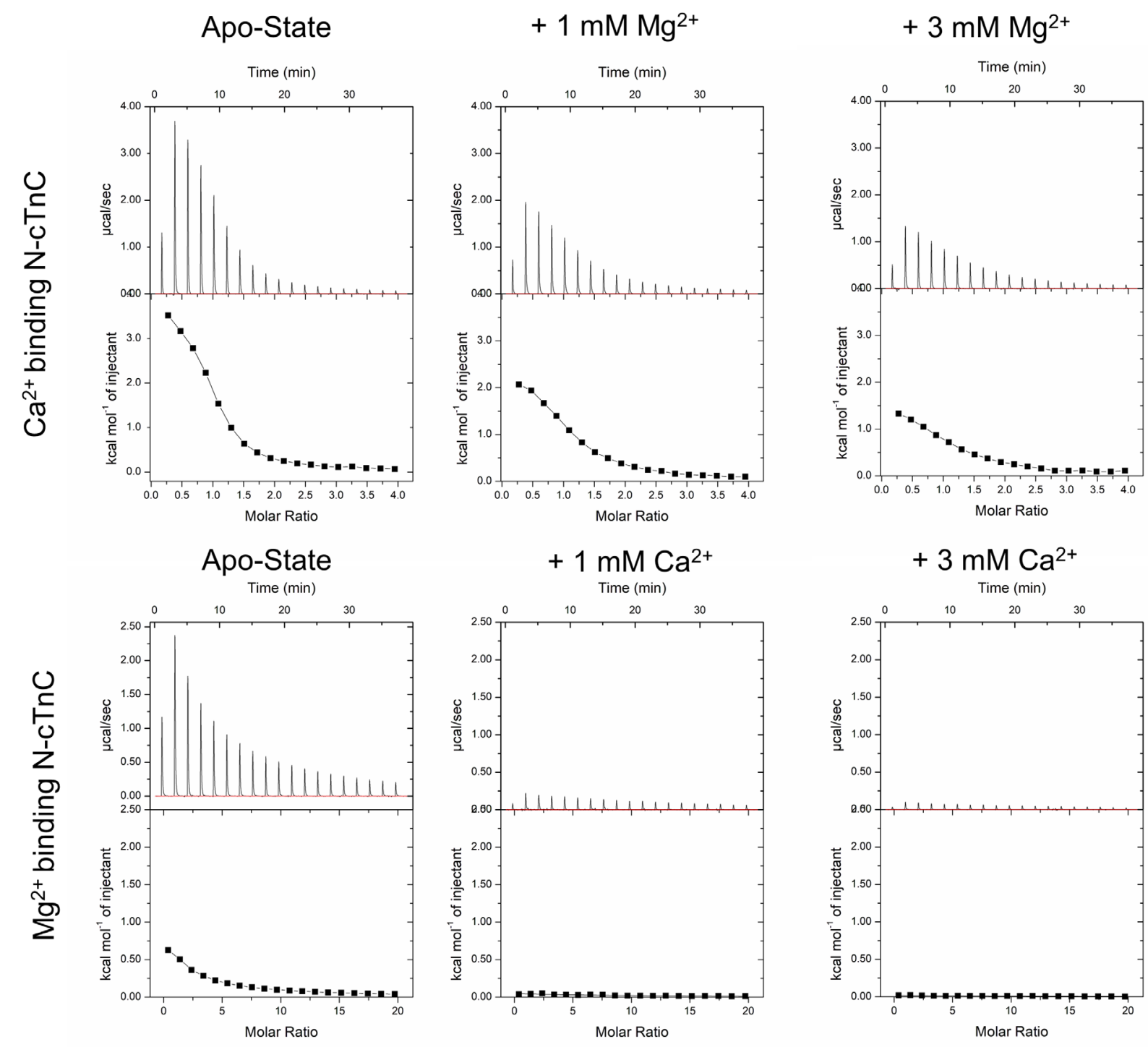

Figure 1 - Representative isotherms of $\mathrm{Ca}^{2+}$ and $\mathrm{Mg}^{2+}$ binding to to apo-state and pre-incubated N-cTnC

Upper panels show the heat recorded during the titration and lower panels plot the integrated heat signal against the molar ratio of titrant added. The top row shows the titration of $4 \mathrm{mM} \mathrm{Ca}^{2+}$ into apo-state $\mathrm{N}-\mathrm{cTnC}$, followed by the same titration into $1 \mathrm{mM}$ and $3 \mathrm{mM} \mathrm{Mg}^{2+}$ pre-incubated $\mathrm{N}$-cTnC. The bottom row shows the titration of 20 $\mathrm{Mg}^{2+}$ into apo-state $\mathrm{N}-\mathrm{cTnC}$, followed by 1 and $3 \mathrm{mM} \mathrm{Ca}^{2+}$ pre-incubated $\mathrm{N}-\mathrm{cTnC}$. The fitting of integrated heats was achieved using a single binding site model.

\section{$\mathrm{Ca}^{2+}$ and $\mathrm{Mg}^{2+}$ binding to apo-state $\mathrm{N}-\mathrm{cTnC}$}

The interaction of $\mathrm{N}-\mathrm{cTnC}$ with either $\mathrm{Ca}^{2+}$ or $\mathrm{Mg}^{2+}$ was found to be associated with a positive $\Delta \mathrm{H}$, so the interaction is driven by entropy (Figure 1) consistent with previously published data (Skowronsky, Schroeter et al. 2013, Tanaka, Takahashi et al. 2013, Stevens, Rayani et al. 2016, 
Stevens, Rayani et al. 2017). This supports our interpretation that the endothermic component between full-length cTnC and $\mathrm{Ca}^{2+}$ is due to binding to the $\mathrm{N}$-doman.

The affinity of $\mathrm{N}-\mathrm{cTnC}$ for $\mathrm{Ca}^{2+}\left(\mathrm{K}_{\mathrm{d}}=15.2 \pm 0.5 \mu \mathrm{M}\right)$ was found to be more than 42.9-fold greater than for $\mathrm{Mg}^{2+}\left(\mathrm{K}_{d}=652.8 \pm 28.4 \mu \mathrm{M}\right)$ difference (Figures 1 and 2; Table S2).
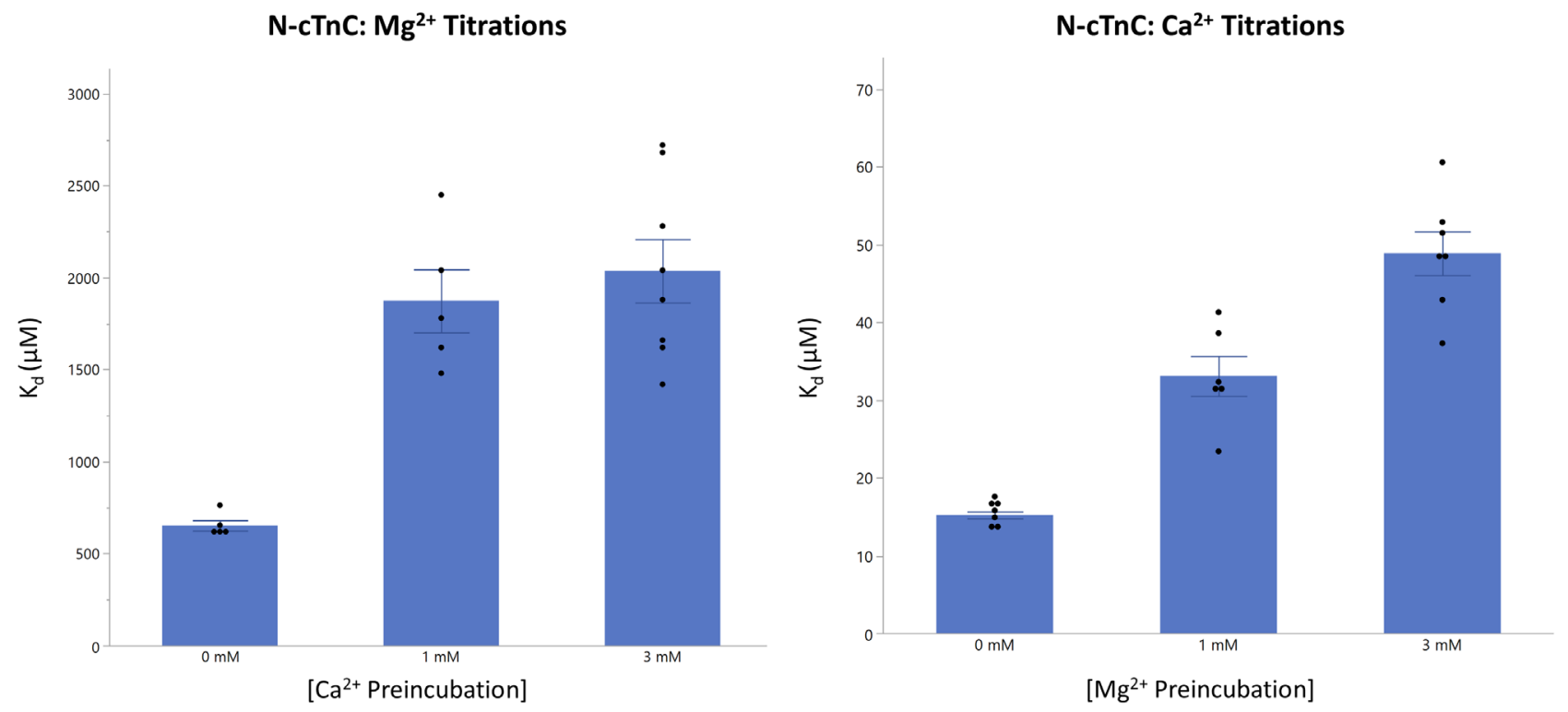

Figure 2 - Binding of $\mathrm{Ca}^{2+}$ and $\mathrm{Mg}^{2+}$ to apo-state and pre-incubated $\mathrm{N}-\mathrm{cTnC}$

Left panel: The affinity of site II for $\mathrm{Mg}^{2+}$ is compared in the apo-state and with $\mathrm{Ca}^{2+}$ preincubation in $\mathrm{N}-\mathrm{cTnC}$; Right Panel: The affinity of site II for $\mathrm{Ca}^{2+}$ is compared in the apo-state and with $\mathrm{Mg}^{2+}$ preincubation in $\mathrm{N}-\mathrm{cTnC}$. Statistical differences were assessed through ANOVA followed by Tukey's post hoc test. $\mathrm{Ca}^{2+}$ titrations were not significantly different but the titration of $\mathrm{Mg}^{2+}$ into $\mathrm{N}-\mathrm{cTnC}$ pre-incubated with $1 \mathrm{mM} / 3 \mathrm{mM} \mathrm{Ca}^{2+}$ was signiferently different from the apo-state titration.

The $\Delta \mathrm{H}$ of the $\mathrm{Ca}^{2+}-\mathrm{N}-\mathrm{cTnC}$ interaction was significantly greater $\left(3.82 \pm 0.04 \mathrm{kcal}^{*} \mathrm{~mol}^{-1}\right)$ than that with $\mathrm{Mg}^{2+}\left(2.64 \pm 0.10 \mathrm{kcal}^{*} \mathrm{~mol}^{-1}\right)$. Moreover, the entropic contribution for the $\mathrm{Ca}^{2+}$ titrations $\left(\mathrm{T}^{*} \Delta S\right.$ $\left.=10.39 \pm 0.03 \mathrm{kcal}^{*} \mathrm{~mol}^{-1}\right)$ was more favorable than the $\mathrm{Mg}^{2+}$ titrations $\left(\mathrm{T}^{*} \Delta \mathrm{S}=6.99 \pm 0.07 \mathrm{kcal}^{*} \mathrm{~mol}^{-1}\right)$ (Table S2).

As expected, the affinity of $\mathrm{Ca}^{2+}$ binding to apo-state $\mathrm{N}-\mathrm{cTnC}$ was also found to be characterized by the lowest observed dissociation constant $\left(\mathrm{K}_{d}\right)(15.2 \pm 0.5 \mu \mathrm{M})$ of all the titration conditions carried out, including pre-incubation (Figure 2 and Table S2).

\section{$\mathrm{Mg}^{2+}$ binding to $\mathrm{Ca}^{2+}$ pre-incubated $\mathrm{N}-\mathrm{CTnC}$}

To investigate $\mathrm{Mg}^{2+}$ binding, apo-state $\mathrm{N}-\mathrm{cTnC}$ was pre-incubated with increasing concentrations of $\mathrm{Ca}^{2+}(0,1$, and $3 \mathrm{mM})$, then titrated with $20 \mathrm{mM} \mathrm{Mg}^{2+}$ (Figure 1 and 2; Table S2). $\mathrm{Mg}^{2+}$ binding the apo-state $\mathrm{N}-\mathrm{cTnC}$ occurred with significantly lower affinity $(652.8 \pm 28.4 \mu \mathrm{M})$ than the $\mathrm{Ca}^{2+}$ titration $(15.2 \pm 0.5 \mu \mathrm{M})$. Moreover, the change in enthalpy in these conditions was significantly 
lower as increasing amounts of $\mathrm{Ca}^{2+}$ was pre-incubated. Titration of $\mathrm{Mg}^{2+}$ into apo-state protein yielded a $\Delta \mathrm{H}=2.64 \pm 0.10 \mathrm{kcal}^{*} \mathrm{~mol}^{-1}$, an order of magnitude lower than $\mathrm{Ca}^{2+}$ into apo-protein which liberated $3.82 \pm 0.04 \mathrm{kcal}^{*} \mathrm{~mol}^{-1}$. Moreover, the $\mathrm{K}_{d}$ values were $1870.0 \pm 171.5 \mu \mathrm{M}$ and $2037.5 \mu \mathrm{M} \pm 172.2 \mu \mathrm{M}$ for the $1 \mathrm{mM}$ and $3 \mathrm{mM} \mathrm{Ca}^{2+}$ conditions, showing a decrease in affinity with increasing concentrations of $\mathrm{Ca}^{2+}$ pre-incubated with the protein sample and a more than 2 orders of magnitude lower affinity compare to the $\mathrm{Ca}^{2+}$ into WT condition. The significant reduction in affinity, $\Delta \mathrm{H}$, and increasingly smaller $\Delta \mathrm{S}$ associated with higher $\mathrm{Ca}^{2+}$ pre-incubation suggests that both metal cations may be binding to the same EF-hand binding motif in site II of $\mathrm{N}-\mathrm{cTnC}$.

\section{$\mathrm{Ca}^{2+}$ binding to $\mathrm{Mg}^{2+}$ pre-incubated $\mathrm{N}$-cTnC}

Apo-protein pre-incubated with $\mathrm{Mg}^{2+}$ was titrated with $\mathrm{Ca}^{2+}$ to assess the "apparent" affinity of the protein for $\mathrm{Ca}^{2+}$ when the site might be occupied with the other divalent cations. As expected, increasing the $\mathrm{Mg}^{2+}$ concentration reduced the amount $\Delta \mathrm{H}$ associated with binding from $3.82 \pm 0.04$ $\mathrm{kcal}^{*} \mathrm{~mol}^{-1}$ in the apo titration to $1.73 \pm 0.05 \mathrm{kcal}^{*} \mathrm{~mol}^{-1}$ in the $3 \mathrm{mM} \mathrm{Mg}^{2+}$ pre-incubated construct. The binding affinity similarily changed from $15.2 \pm 0.5 \mu \mathrm{M}$ to $48.9 \pm 2.8 \mu \mathrm{M}$. The $\mathrm{Ca}^{2+}$ affinity was lower compared to the apo-N-cTnC binding condition and decreased with higher concentrations of $\mathrm{Mg}^{2+}$ (Figure 2 and Table S2). 


\section{$\mathrm{Ca}^{2+}$ and $\mathrm{Mg}^{2+}$ binding to apo-D67A/D73A $\mathrm{N}-\mathrm{CTnC}$}
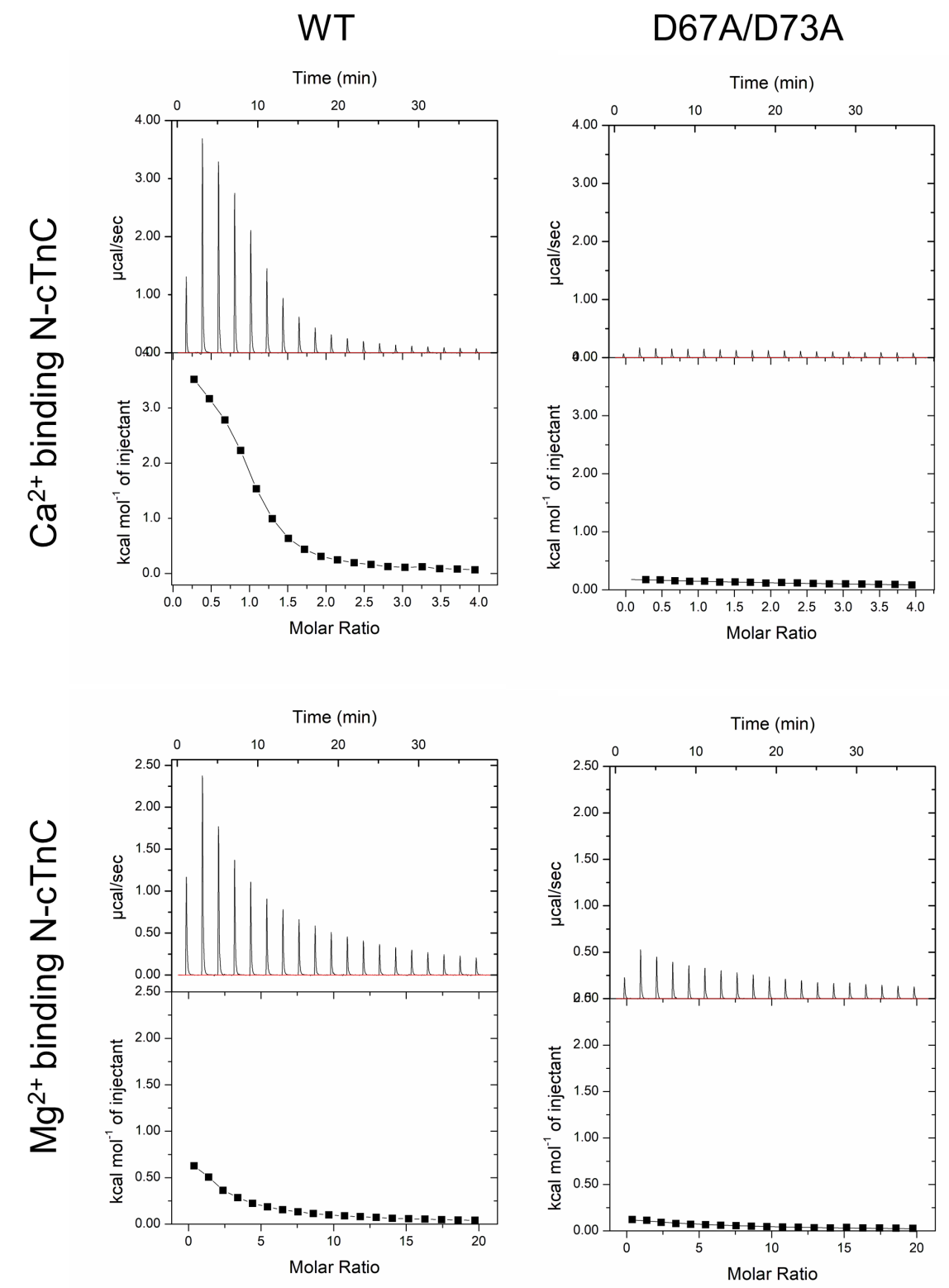

Figure 3 - Representative binding isotherms for binding of $\mathrm{Ca}^{2+}$ and $\mathrm{Mg}^{2+} \mathrm{WT}$ and D67A/D73A NcTnC

The top row shows the titration of $4 \mathrm{mM} \mathrm{Ca}^{2+}$ into apo-state $\mathrm{N}-\mathrm{cTnC}$, followed by the same titration into the D67A/D73A mutant. The bottom row shows the titration of $20 \mathrm{mM} \mathrm{Mg}^{2+}$ into apo-state $\mathrm{N}-\mathrm{cTnC}$, followed by the same titration into the D67A/D73A mutant. The fitting of integrated heats was achieved using a single binding site model.

Point mutations (D67A and D73A) were made (Figure S2), affecting two known Ca ${ }^{2+}$ coordinating residues in site II. Binding of both divalent cations was reduced by these mutations but the $\mathrm{K}_{d}$ was still lower for $\mathrm{Ca}^{2+}$ binding $(180.3 \pm 16.2 \mu \mathrm{M})$ compared to $\mathrm{Mg}^{2+}$ binding $(1148.6 \pm 95.0 \mu \mathrm{M})$ (Figures 3 and 4; Table S2). Compared to the WT, $\mathrm{Ca}^{2+}$ binding was reduced 11.9-fold and $\mathrm{Mg}^{2+}$ binding was reduced 1.8 -fold by the double mutation. The change in affinity was significantly higher for the $\mathrm{Ca}^{2+}$ titrations but statistically indifferent for $\mathrm{Mg}^{2+}$. 

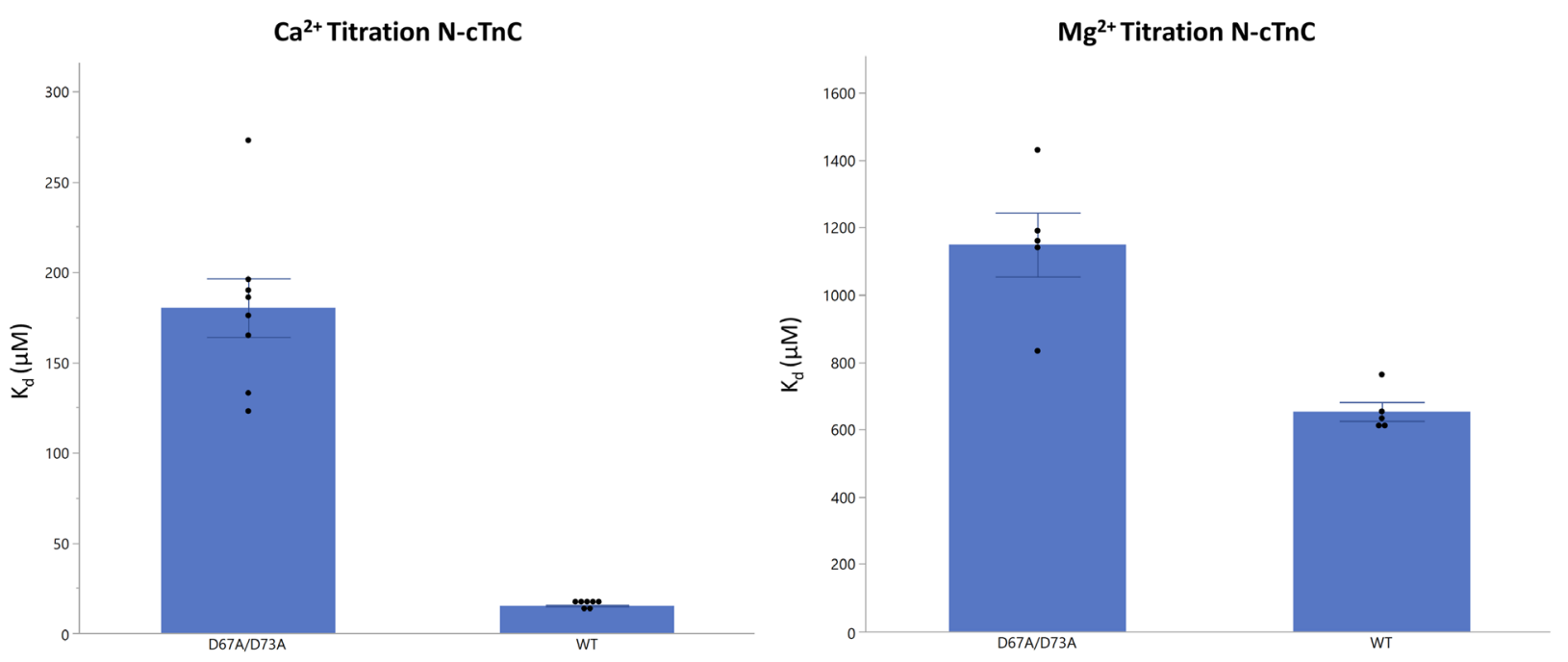

Figure 4 - Binding of $\mathrm{Ca}^{2+}$ and $\mathrm{Mg}^{2+}$ to WT and D67A/D73A N-cTnC

The effect of the D67A/D73A on $\mathrm{Ca}^{2+}$ and $\mathrm{Mg}^{2+}$ binding is assessed. The affinity of binding for both cations to $\mathrm{N}$ cTnC was lower when comparing the mutant and the WT. The effect on $\mathrm{Ca}^{2+}$ binding was more pronounced (11.9-fold reduction) compared to $\mathrm{Mg}^{2+}$ (1.8-fold reduction) but this is reconcilable with the number of coordinating residues needed to bind $\mathrm{Ca}^{2+}(6)$ vs. $\mathrm{Mg}^{2+}(5)$; having 4 available coordinating residues was expected to affect $\mathrm{Ca}^{2+}$ binding to a greater extent.

\section{$\mathrm{Ca}^{2+}$ and $\mathrm{Mg}^{2+}$ binding affinities from Thermodynamic Integration}

Thermodynamic Integration ( $\mathrm{TI})$ was performed to calculate absolute binding affinities for the ions in the following systems: $\mathrm{Ca}^{2+}$ to WT N-cTnC, $\mathrm{Ca}^{2+}$ to D67A/D73A N-cTnC, $\mathrm{Mg}^{2+}$ to WT N-cTnC, and $\mathrm{Mg}^{2+}$ to D67A/D73A N-cTnC. The average calculated binding affinities over 5 independent runs were $-6.9 \pm 1.3,-4.5 \pm 2.4,-0.6 \pm 2.8$, and $+0.4 \pm 2.3 \mathrm{kcal}^{*} \mathrm{~mol}^{-1}$, respectively. The TI-determined $\mathrm{Ca}^{2+}$ binding affinities were in good agreement with the ITC data. While the calculated absolute $\mathrm{Mg}^{2+}$ binding affinities were not in perfect agreement with the ITC data, they did show that $\mathrm{Mg}^{2+}$ had a weaker binding affinity than $\mathrm{Ca}^{2+}$ for all systems $\left(-6.57\right.$ to $-4.38 \mathrm{kcal}^{*} \mathrm{~mol}^{-1}$ and -6.9 to $-0.6 \mathrm{kcal}^{*} \mathrm{~mol}^{-1}$ for ITC and TI, respectively for WT system and -5.12 to $-4.02 \mathrm{kcal}^{*} \mathrm{~mol}^{-1}$ and -4.5 to $+0.4 \mathrm{kcal}^{*} \mathrm{~mol}^{-1}$ for ITC and TI, respectively for D67A/D73A system). Additionally, between the $\mathrm{Mg}^{2+}$ binding affinities, the binding affinity was consistently weaker for the D67A/D73A mutation. The $\Delta \triangle G$ values comparing $\Delta G$ between WT and D67A/D73A systems were similar for ITC and TI $\left(0.36 \mathrm{kcal}^{*} \mathrm{~mol}^{-1}\right.$ and $1.0 \mathrm{kcal}^{*} \mathrm{~mol}^{-1}$, respectively). 
Table 1 - Average calculated binding affinities for each Thermodynamic Integration system

\begin{tabular}{|c|c|}
\hline System & $\Delta \mathrm{G}_{\mathrm{TI}}\left(\mathrm{kcal}^{*} \mathrm{~mol}^{-1}\right)$ \\
\hline $\mathrm{Ca}^{2+}$ to WT & $-6.9 \pm 1.3$ \\
\hline $\mathrm{Ca}^{2+}$ to D67A/D73A & $-4.5 \pm 2.4$ \\
\hline $\mathrm{Mg}^{2+}$ to WT & $-0.6 \pm 2.8$ \\
\hline $\mathrm{Mg}^{2+}$ to D67A/D73A & $+0.4 \pm 2.0$ \\
\hline
\end{tabular}

Averages were calculated over 5 independent runs

\section{Full length cTnC}
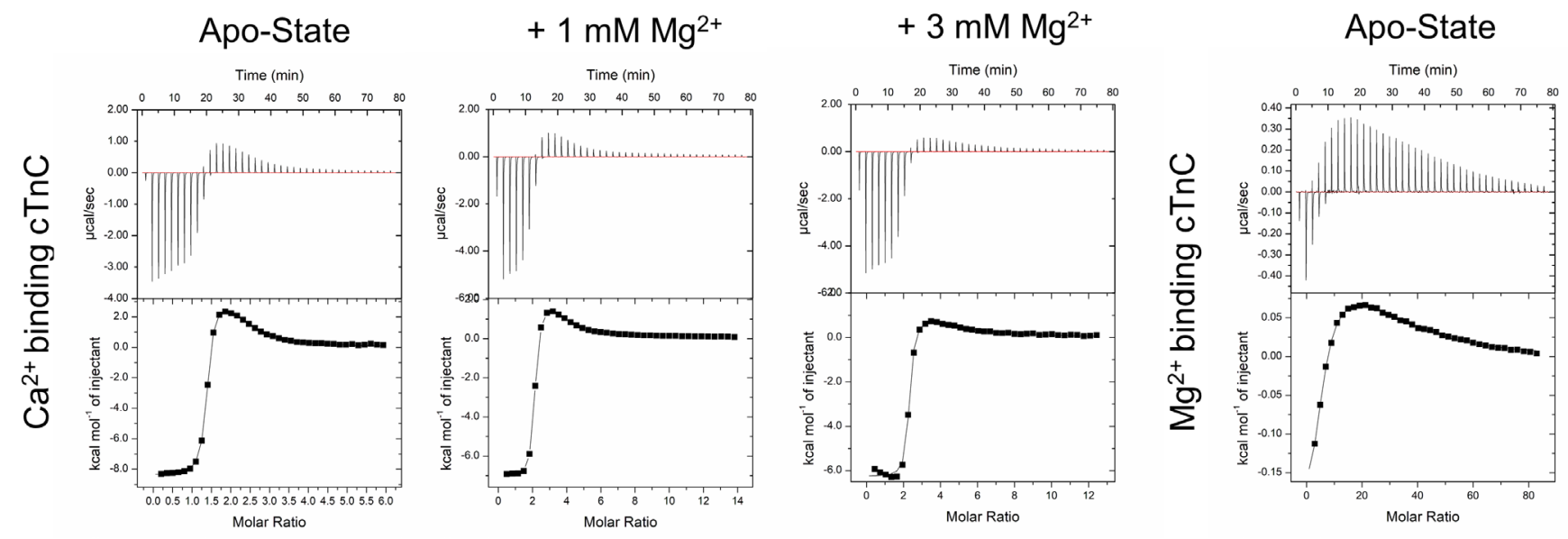

Figure 5 - Representative isotherms for binding of $\mathrm{Ca}^{2+}$ and $\mathrm{Mg}^{2+}$ to full length $\mathrm{cTnC}$

Representative isotherms for each full-length cTnC titration condition are shown. Upper panels show the heat recorded during the titration and lower panels plot the integrated heat signal against the molar ratio of titrant added. A two sets of binding sites model was used to fit the integrated heats. From left to right, the panels show: the titration of $6 \mathrm{mM} \mathrm{Ca}^{2+}$ into: apo-state full length $\mathrm{cTnC}, 1 \mathrm{mM} \mathrm{Mg}{ }^{2+}$ incubated cTnC, and $3 \mathrm{mM} \mathrm{Mg}^{2+}$ incubated cTnC. The isotherms can be used to visually determine the decreased amount of binding to site II in the presence of increasing $\mathrm{Mg}^{2+}$. In the right most panel of this figure, the binding of $\mathrm{Mg}^{2+}$ to apo-state full-length cTnC occurs at two sets of different sites as seen in the isotherm which contains both exothermic and endothermic components.

\section{$\mathrm{Ca}^{2+}$ binding to apo-state full length cTnC}

Binding of $\mathrm{Ca}^{2+} / \mathrm{Mg}^{2+}$ to site II is characterized by an endothermic interaction as indicated by our titrations on the N-terminal domain in this and previous publications (Stevens, Rayani et al. 2016, Stevens, Rayani et al. 2017). From this, and ITC work on full-length cTnC by others (Johnson, Fulcher et al. 2019), we can deduce that the exothermic interactions seen above (Figure 5) result from interactions with site III/IV. The data (Figure 5 and Table S3) show that $\mathrm{Mg}^{2+}$ binds to apo-state fulllength cTnC at two distinct sets of sites. 
The binding of $\mathrm{Ca}^{2+}$ to sites III/IV occurred with an apparent $\mathrm{K}_{d}$ of $0.12 \pm 0.02 \mu \mathrm{M}$, characterized by an exothermic component $\left(\Delta \mathrm{H}=-8.12 \pm 0.07 \mathrm{kcal}^{*} \mathrm{~mol}^{-1}\right)$ with a positive change in entropy $\left(T^{*} \Delta S=1.24 \pm 0.07 \mathrm{kcal}^{*} \mathrm{~mol}^{-1}\right)$. In the same full-length construct, the $\mathrm{K}_{\mathrm{d}}$ associated with binding of $\mathrm{Ca}^{2+}$ to site II was $22.7 \pm 0.5 \mu \mathrm{M}$ significantly lower binding affinity. It also had positive $\Delta \mathrm{H}$ $\left(3.71 \pm 0.06 \mathrm{kcal}^{*} \mathrm{~mol}^{-1}\right)$ and was entropically driven $\left(T^{*} \Delta S=10.0 \pm 0.07 \mathrm{kcal}^{*} \mathrm{~mol}^{-1}\right)$ (Figure 5 and 6; Table S3).

\section{$\mathrm{Mg}^{2+}$ binding to apo-state full length $\mathrm{cTnC}$}

$\mathrm{Mg}^{2+}$ binding to site II $\left(\mathrm{K}_{\mathrm{d}}=406.1 \pm 7.9 \mu \mathrm{M}\right)$ and sites III/IV $\left(\mathrm{K}_{d}=16.7 \pm 0.7 \mu \mathrm{M}\right)$ was characterized by a positive $\Delta \mathrm{H}\left(0.091 \pm 0.001 \mathrm{kcal}^{*} \mathrm{~mol}^{-1}\right)$ and negative $\Delta \mathrm{H}\left(-0.23 \pm 0.01 \mathrm{kcal}^{*} \mathrm{~mol}^{-1}\right)$, respectively (Figure 5 and Table S3). Based on these enthalpy values, significantly greater amounts of $\mathrm{Mg}^{2+}$ binding occur at the $\mathrm{C}$-terminus in comparison to the $\mathrm{N}$-terminus.

The interaction of $\mathrm{Mg}^{2+}$ with sites III/IV is two orders of magnitude weaker than that seen for $\mathrm{Ca}^{2+}$. The interaction with site II and sites III/IV were both entropically favorable $\left(T^{*} \Delta S=4.71 \pm 0.01\right.$ $\mathrm{kcal}^{*} \mathrm{~mol}^{-1}$ and $\left.\mathrm{T}^{*} \Delta \mathrm{S}=6.28 \pm 0.03 \mathrm{kcal}^{*} \mathrm{~mol}^{-1}\right)$ and resulted in spontaneous interactions $(\Delta \mathrm{G}=-4.62 \pm$ $0.11 \mathrm{kcal}^{*} \mathrm{~mol}^{-1}$ and $\left.\Delta G=-6.51 \pm 0.31 \mathrm{kcal}^{*} \mathrm{~mol}^{-1}\right)$. These all differed significantly from those observed for $\mathrm{Ca}^{2+}$ binding, $\mathrm{p}<0.05$.

\section{$\mathrm{Ca}^{2+}$ binding to $\mathrm{Mg}^{2+}$ pre-incubated full length cTnC}

At greater concentrations, $\mathrm{Mg}^{2+}$ occupied a greater proportion of binding sites and limited binding $\mathrm{Ca}^{2+}$ to cTnC at all sites (Figure 5 and 6; Table S3). Binding of $\mathrm{Ca}^{2+}$ to site II was significantly reduced by pre-incubation with $1 \mathrm{mM}$ and $3 \mathrm{mM} \mathrm{Mg}^{2+}$ as indicated by an increase in $\mathrm{K}_{d}$ and a lowering of the $\Delta \mathrm{H}$. Binding of $\mathrm{Ca}^{2+}$ to sites III/IV in the presence of $1 \mathrm{mM} \mathrm{Mg}^{2+}$ resulted in a $\mathrm{K}_{\mathrm{d}}(0.14 \pm 0.01 \mu \mathrm{M})$ that was not significantly different $(p<0.05)$ than seen for the $3 \mathrm{mM} \mathrm{Mg}^{2+}$ preincubation $\left(\mathrm{K}_{d}=0.08 \pm\right.$ $0.01 \mu \mathrm{M})$ (Figure 5 and Table S3). 
$\mathrm{Ca}^{2+}$ Titrations: WT cTnC Site II

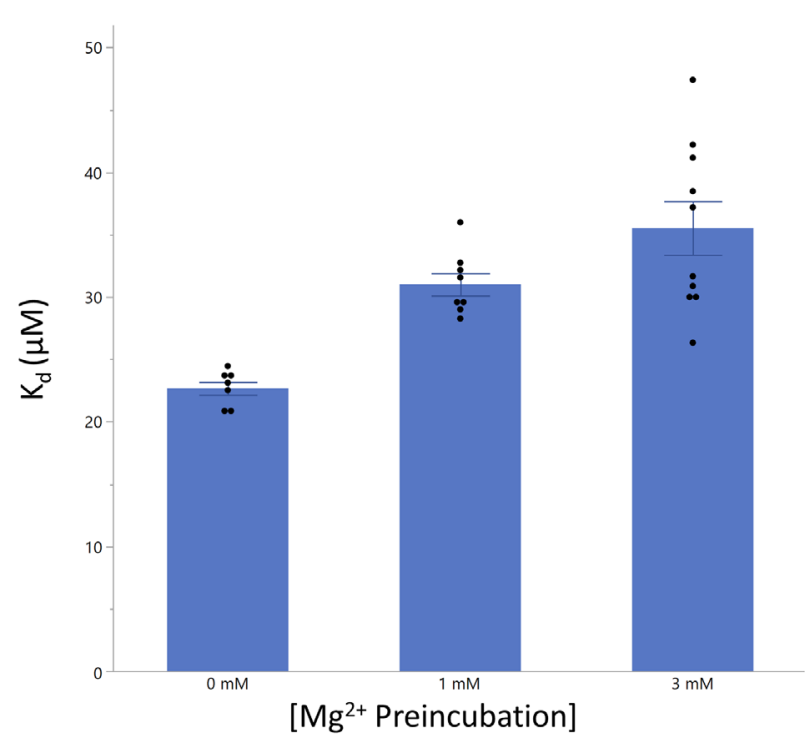

$\mathrm{Ca}^{2+}$ Titrations: WT cTnC Sites III and IV

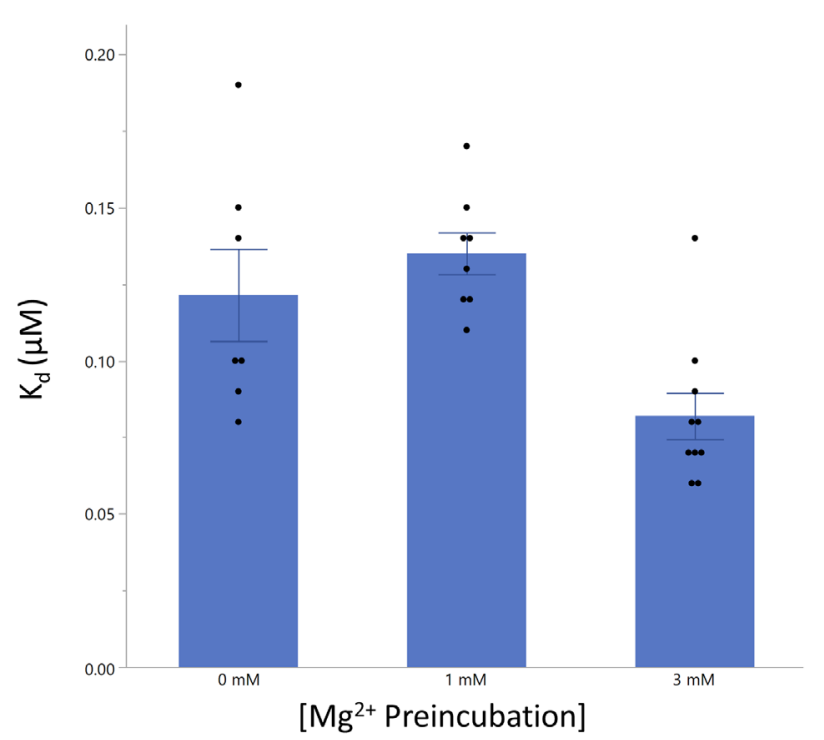

Figure 6 - Binding of $\mathrm{Ca}^{2+}$ and $\mathrm{Mg}^{2+}$ to apo-state and pre-incubated full length $\mathrm{cTnC}$

Left panel: The affinity of site II for $\mathrm{Ca}^{2+}$ is compared in the apo-state and with $\mathrm{Mg}^{2+}$ preincubation in full length cTnC; Right Panel: The affinity of sites III/IV for $\mathrm{Ca}^{2+}$ is compared in the apo-state and with $\mathrm{Mg}^{2+}$ preincubation in full length cTnC. At site II, preincubation with 1 and $3 \mathrm{mM} \mathrm{Mg}^{2+}$ caused a significant reduction in the affinity for $\mathrm{Ca}^{2+}$ binding. At sites III/IV, preincubation with $1 \mathrm{mM} \mathrm{Mg}^{2+}$ decreased affinity for $\mathrm{Ca}^{2+}$ binding (not statistically significant), while $3 \mathrm{mM} \mathrm{Mg}{ }^{2+}$ unexpectedly increased the affinity for $\mathrm{Ca}^{2+}$ binding at these sites. Statistical differences were assessed through two-way ANOVA followed by Tukey's post hoc test.

At sites III/IV, for the $1 \mathrm{mM} \mathrm{Mg}^{2+}$ pre-incubation, the interaction proceeded with favorable enthalpy $\left(\Delta \mathrm{H}=-6.87 \pm 0.09 \mathrm{kcal}^{*} \mathrm{~mol}^{-1}\right)$ and entropy $\left(T^{*} \Delta S=2.50 \pm 0.10 \mathrm{kcal}^{*} \mathrm{~mol}^{-1}\right)$. For the $3 \mathrm{mM}$ $\mathrm{Mg}^{2+}$ condition, the reaction was again exothermic $\left(\Delta \mathrm{H}=-6.19 \pm 0.06 \mathrm{kcal}^{*} \mathrm{~mol}^{-1}\right)$ with a positive change in $\mathrm{T}^{\star} \Delta \mathrm{S}\left(3.50 \pm 0.06 \mathrm{kcal}^{*} \mathrm{~mol}^{-1}\right)$. 


\section{Discussion}

This study provides novel information regarding the thermodynamics that underlie the interaction between cTnC and two physiologically prevalent divalent cations. Our results significantly advance the understanding of the mechanisms and role of modifications in cellular $\mathrm{Mg}^{2+}$ in control of the $\mathrm{cTnC} \mathrm{Ca}{ }^{2+}$ switch. Cellular free $\mathrm{Mg}^{2+}$ is known to change in pathological conditions in the heart, but mechanisms of its effects on activation of the myofilaments remains incompletely understood.

As seen in previous reports, we found the binding of $\mathrm{Ca}^{2+}$ to $\mathrm{N}-\mathrm{cTnC}$ to be driven by entropy and unfavorable enthalpy (Table S2) (Stevens, Rayani et al. 2017, Johnson, Fulcher et al. 2019). The favorable $\Delta S$ may be due in part to the hydration enthalpy of $\mathrm{Ca}^{2+}$ which is thought to be on the order of $\sim 375 \mathrm{kcal}^{*} \mathrm{~mol}^{-1}$ and slightly lower than that of $\mathrm{Mg}^{2+}\left(\sim 460 \mathrm{kcal}^{*} \mathrm{~mol}^{-1}\right)$ (Smith DW, 1977). It is also possible that the endothermic nature of these interactions results from other factors such as the exchange of protons that are transferred from the ligand to the buffer upon $\mathrm{Ca}^{2+}$ binding (Skowronsky, Schroeter et al. 2013).

Measurement of $\mathrm{Ca}^{2+}$ binding to $\mathrm{cTnC}$ is often achieved indirectly by measuring the fluorescence change and correlating this to the conformational change that results from the interaction. Fluorescent molecules such as IAANS (Wang, Huang et al. 1997, Hazard, Kohout et al. 1998, Li, Stevens et al. 2013) or reporters such as F27W (Gillis, Blumenschein et al. 2003) can be used to quantify this binding interaction. At $21^{\circ} \mathrm{C}$ bovine $\mathrm{F} 27 \mathrm{~W}$ cTnC had a $\mathrm{K}_{d}$ of $\sim 5 \mu \mathrm{M}$ and IAANS labelled C35S cTnC had a $\mathrm{K}_{d}$ of $\sim 7 \mu \mathrm{M}$ (Gillis, Marshall et al. 2000, Tikunova and Davis 2004). Through fluorescence-based measurement, the $\mathrm{K}_{d}$ of $\mathrm{N}-\mathrm{cTnC}$ for $\mathrm{Ca}^{2+}$ was previously reported to be between 11.3 $\mu \mathrm{M}$ - 12.3 $\mu \mathrm{M}$ (Liang, Chung et al. 2008, Pinto, Parvatiyar et al. 2009). These parameters agree with our measured $\mathrm{Ca}^{2+}$ binding to apo-state $\mathrm{N}$-cTnC and apo-state cTnC (Table S2), deviating only slightly due to buffer and temperature conditions.

Normally, cytosolic $\left[\mathrm{Mg}^{2+}\right]_{\text {free }}$ is maintained around $\sim 0.5-1 \mathrm{mM}$ (Romani 2011). At these concentrations, $\mathrm{Mg}^{2+}$ is known to compete with $\mathrm{Ca}^{2+}$ for sites III and IV. Circular dichroism has been used to show that $\mathrm{Ca}^{2+}$ binding to sites III/IV increases the $\alpha$-helical content of cTnC, from 19 to 41 percent (Herzberg and James 1985, Yumoto, Nara et al. 2001) and causes conformational changes that remove non-polar amino acids from the solvent exposed environment (Sturtevant 1977). This contrasts with NMR-based visualization of $\mathrm{N}-\mathrm{cTnC}$, in which the apo-state and $\mathrm{Ca}^{2+}$-bound forms showed minimal structural deviation (Spyracopoulos, Li et al. 1997).

$\mathrm{Ca}^{2+}$ has many times greater polarizability than $\mathrm{Mg}^{2+}$ and lower hydration energy (Carafoli and Krebs 2016). The bare ion radius of $\mathrm{Mg}^{2+}(0.65 \AA)$ is smaller than $\mathrm{Ca}^{2+}(0.99 \AA)$ (Lockless, Zhou et al. 
2007), conversely, in its hydrated form $\mathrm{Mg}^{2+}(4.3 \AA)$ is larger than $\mathrm{Ca}^{2+}(4.1 \AA)$ (Maguire 2006). In other $\mathrm{Ca}^{2+}$ binding proteins such as calmodulin (CaM), metals with similar ionic radii are able to substitute for this cation (Chao, Suzuki et al. 1984, Malmendal, Linse et al. 1999). Mg $^{2+}$ is able to bind to CaM, but does not induce the conformational change associated with $\mathrm{Ca}^{2+}$ binding; a phenomenon that is commonly observed in cell biology (Follenius and Gerard 1984, Gilli, Lafitte et al. 1998).

Normally, six oxygen atoms arranged in an octahedral geometry are thought to coordinate $\mathrm{Mg}^{2+}$ (Linse and Forsen 1995). This is one less oxygen than needed to coordinate $\mathrm{Ca}^{2+}$ through a pentagonal bipyramid (Cates, Berry et al. 1999). However, $\mathrm{Ca}^{2+}$ can be coordinated by $6-8$ coordinating residues (but also by as many as 12 ) at a distance that can vary greatly $(2.3-2.7 \AA)$ compared to a much smaller variance for $\mathrm{Mg}^{2+}$ coordination (2.0 - 2.2 $\AA$ ) (Brini, Cali et al. 2012).

$\mathrm{Ca}^{2+}$ and $\mathrm{Mg}^{2+}$ are most often coordinated by oxygen atoms, this is usually a hydroxyl group for $\mathrm{Mg}^{2+}$ and a carboxyl group for $\mathrm{Ca}^{2+}$ (Harding 2002). $\mathrm{Ca}^{2+}$ is most frequently coordinated by side chains of aspartic acid, glutamic acid, asparagine, followed by serine/threonine, while $\mathrm{Mg}^{2+}$ is most frequently coordinated by aspartic acid, glutamic acid, histidine, threonine, serine, and asparagine. (Dokmanic, Sikic et al. 2008). EF hand-containing proteins have also been shown to bind $\mathrm{Mg}^{2+}$ when there are appropriately placed negatively charged amino residues (especially in the $+z$ and $-z$ positions) (Reid and Procyshyn 1995, Tikunova, Black et al. 2001, Davis, Rall et al. 2002). In site II of mammalian cTnC, there is a polar serine at the $+z$ position (residue 69) and a negatively charged glutamic acid at the $-\mathrm{z}$ position (residue 76) (Figure $\mathbf{S 1}$ ).

Data from earlier studies suggested $\mathrm{Mg}^{2+}$ bound exclusively at sites III and IV of TnC (Potter and Gergely 1975). Shortly thereafter, a limited series of equilibrium dialysis experiements did not show competition between $\mathrm{Mg}^{2+}$ and $\mathrm{Ca}^{2+}$ for the $\mathrm{N}$-terminal sites of $\mathrm{cTnC}$, instead, other binding sites were suggested (Holroyde, Robertson et al. 1980). Later still, enthalpic titrations were unable to visualize a discernable change in $\mathrm{Mg}^{2+}$ binding to the low affinity sites of skeletal TnC (Yamada and Kometani 1982, Li, Chandra et al. 1994). However, assuming competitive binding fluorescence assays at room temperature determined the $\mathrm{K}_{\mathrm{d}}$ associated with $\mathrm{Mg}^{2+}$ binding to be about $4 \mathrm{mM}$ (Johnson, Collins et al. 1980). More recently, $\mathrm{Ca}^{2+}$ sensitivity of the actomyosin ATPase and force production of skinned rat cardiac cells was unaltered when $\mathrm{Mg}^{2+}$ was increased from 1 to $8 \mathrm{mM}$ (Allen, Xu et al. 2000). These findings were brought into question, however, by studies that utilized metallochromic indicators to deduce sufficiently high $\mathrm{Mg}^{2+}$-affinity at the regulatory sites of skeletal TnC (Ogawa 1985).

The observation of $\mathrm{Mg}^{2+}$ binding to the low affinity sites of $\mathrm{N}-\mathrm{cTnC}$ has led to the suggestion that differences in affinity may be due at least in part to the $\mathrm{Ca}^{2+}$ buffering and thus the free 
concentration of the ion in these experiments. Given the kinetic rates associated with these interactions, it is difficult to have confidence in EGTA determined rates of binding (Ebashi and Ogawa 1988). Moreover, given the temperature sensitivity of cTnC, this factor alone can alter experimental outcomes by orders of magnitude (Kohama 1980, Gillis, Moyes et al. 2003). Change in sensitivity in the face of altered temperature has been suggested to result mostly from binding to the low affinity sites and possibly through interactions with other members of the Tn complex (Godt and Lindley 1982, Stephenson and Williams 1982, Wnuk, Schoechlin et al. 1984).

Experiments testing the effects of alterations in free $\mathrm{Mg}^{2+}$ on $\mathrm{Ca}^{2+}$-activation of isolated myofibrils and skinned fiber bundles from different laboratories provide corroborative findings supporting the credibility of our postulate of a role for cytosolic $\mathrm{Mg}^{2+}$ as a controller of cTnC function at the $\mathrm{N}$-lobe. Fabiato and Fabiato showed that increasing concentration of free $\mathrm{Mg}^{2+}$ decreases myofilament $\mathrm{Ca}^{2+}$ sensitivity of skinned cardiomyocytes (Fabiato and Fabiato 1975). $\left[\mathrm{Mg}^{2+}\right]$ affects the $\mathrm{Ca}^{2+}$-sensitivity of the myofibrillar ATPase as well as actomyosin tension development in both skeletal and cardiac muscle preparations (Donaldson and Kerrick 1975, Kerrick and Donaldson 1975, Solaro and Shiner 1976, Ashley and Moisescu 1977, Best, Donaldson et al. 1977, Donaldson, Best et al. 1978, Ebashi, Nonomura et al. 1980, Morimoto 1991).

$\mathrm{Mg}^{2+}$ affinity of sites III/IV alone is not sufficient to fully explain the change in the force-pCa relationship caused by $\mathrm{Mg}^{2+}$ in skinned skeletal muscle fibers (Ebashi and Endo 1968). In rabbit fast skeletal muscle, $\mathrm{Mg}^{2+}$ competes with $\mathrm{Ca}^{2+}$ for low affinity binding sites of $\mathrm{TnC}$ where it binds with an affinity of $1.9^{*} 10^{2} \mathrm{M}^{-1}$ (much lower than the $6.2^{*} 10^{6} \mathrm{M}^{-1}$ seen for $\mathrm{Ca}^{2+}$ ). The $\mathrm{K}_{\mathrm{A}}$ associated with sites III and IV was measured to be $1.2^{*} 10^{6} \mathrm{M}^{-1}$ for $\mathrm{Ca}^{2+}$ and $1.1^{*} 10^{2} \mathrm{M}^{-1}$ for $\mathrm{Mg}^{2+}$ in canine ventricular skinned myocytes (Pan and Solaro 1987).

In isolated cTnC, $\mathrm{Mg}^{2+}$ was found to interact with site II of cTnC with an apparent binding constant of $5.2^{*} 10^{2} \mathrm{M}^{-1}$. This was only slightly lower than the constant associated with $\mathrm{Mg}^{2+}$ binding to sites III/IV $\left(\sim 10^{3} \mathrm{M}^{-1}\right), \mathrm{Ca}^{2+}$ binding to sites III/IV $\left(\sim 10^{6} \mathrm{M}^{-1}\right)$, and $\mathrm{Ca}^{2+}$ binding to site II $\left(\sim 10^{4} \mathrm{M}^{-1}\right)$ (Ogawa 1985).

Fluorescence was used to measure the $\mathrm{Mg}^{2+}$ affinity of site II at $15^{\circ} \mathrm{C}(\sim 1.2-1.9 \mathrm{mM})$ (Tikunova and Davis 2004). In the presence of $3 \mathrm{mM} \mathrm{Mg}^{2+}$, the $\mathrm{K}_{\mathrm{d}}$ associated with binding of $\mathrm{Ca}^{2+}$ to site II of full length cTnC was increased from $7 \mu \mathrm{M}$ in the apo-state to $24 \mu \mathrm{M}$ (Tikunova and Davis 2004). Moreover, a system containing cTnC-cTnl had 2.5-fold lower $\mathrm{Ca}^{2+}$ affinity in the presence of $3 \mathrm{mM}$ $\mathrm{Mg}^{2+}$ (Siddiqui, Tikunova et al. 2016). Given these affinities, Tikunova and Davis hypothesized that site II would be $33-44 \%$ saturated by $1 \mathrm{mM}$ cytosolic $\mathrm{Mg}^{2+}$ at diastolic $\mathrm{Ca}^{2+}$ concentrations (Tikunova and Davis 2004). 
In a recent ITC study, the $\mathrm{Mg}^{2+}$ binding affinity of site II in lobster TnC isoforms, which are similar in sequence to human variants, was explored. $\mathrm{Mg}^{2+}$ affinity of site II was a single order of magnitude lower than that of $\mathrm{Ca}^{2+}$, such that the cations would compete for binding (Tanaka, Takahashi et al. 2013) under physiological conditions.

In our experiments on $\mathrm{N}-\mathrm{cTnC}$ and full length $\mathrm{cTnC}$, site II binding affinity of $\mathrm{Mg}^{2+}$ was an order of magnitude lower than seen for $\mathrm{Ca}^{2+}$ (Figures 2 and 6; Table S2 and S3). At these affinities and given the relatively high cytosolic $\left[\mathrm{Mg}^{2+}\right]_{\text {free }}$ (Linse and Forsen 1995, Malmendal, Linse et al. 1999), this cation would compete for binding to site II of cTnC (Nara, Morii et al. 2013). Competition experiements were also in agreement (Figures 1 and 2) as were studies that utilized a double mutant removing coordinating residues in site II (Figures 3 and 4).

In order to further validate the ITC data, we also performed thermodynamic integration (TI) to calculate absolute binding affinities computationally. We performed these calculations for both $\mathrm{Ca}^{2+}$ and $\mathrm{Mg}^{2+}$ binding separately for both WT N-cTnC and D67A/D73A N-cTnC. For both sets of simulations, the structure of $\mathrm{Ca}^{2+}$-bound $\mathrm{N}-\mathrm{cTnC}$ (PDB:1AP4) was used as the starting parameter and restrained throughout the simulation. ITC measures the thermodynamically quantifiable closed-toopen transition of the $\mathrm{N}-\mathrm{cTnC}$ molecule. TI does not allow for such a transition, rather, it quantifies only the binding interaction. In the future, the closed structure of N-cTnC (PDB:1SPY) can be simulated to quantify the presumably lower affinity it has for each of $\mathrm{Ca}^{2+}$ and $\mathrm{Mg}^{2+}$. The difference between these sets of simulations could then be used to better corroborate the ITC data.

For $\mathrm{Ca}^{2+}$ binding, our TI results agreed very well with the binding affinities from ITC. For $\mathrm{Mg}^{2+}$ binding, the calculated absolute binding affinities were consistently underestimated by about 4 $\mathrm{kcal}^{*} \mathrm{~mol}^{-1}$ but showed the same relative trends. $\mathrm{Mg}^{2+}$ was calculated to bind weaker than $\mathrm{Ca}^{2+}$ and bind weaker for the D67A/D73A mutation similarly to ITC. The $\mathrm{Mg}^{2+}$ absolute binding affinities were likely underestimated for multiple reasons. First, the crystal structure of WT N-cTnC (1AP4) contained $\mathrm{Ca}^{2+}$ bound and no structure of $\mathrm{Mg}^{2+}$ bound WT $\mathrm{N}-\mathrm{cTnC}$ was available. We attempted to correct for this issue by minimizing the structure with $\mathrm{Mg}^{2+}$ bound. Due to the lack of an exact starting structure and restraints chosen, there is still likely some error. Additionally, while we did try to choose the most accurate $\mathrm{Mg}^{2+}$ parameters for binding affinity calculation, there are well documented difficulties in free energy calculations for $\mathrm{Mg}^{2+}$, most notably that the free energy of solvation $\left(\Delta \mathrm{G}_{\text {solvation }}\right)$ is consistently underestimated (Steinbrecher, Joung et al. 2011, Panteva, Giambasu et al. 2015). Even when using the same $\mathrm{Mg}^{2+}$ force field, solvation $\Delta \mathrm{G}$ values are also known to have large variations for $\mathrm{Mg}^{2+}$ depending on the exact simulation parameters used. For example, Panteva et al. and Li et al. both tried to reproduce $\mathrm{Mg}^{2+}$ solvation free energy using the same parameters as Åqvist, but saw variations on the order of $20 \mathrm{kcal}^{*} \mathrm{~mol}^{-1}$ (Äqvist 1990). While this may be an extreme example, it illustrates the 
difficulty in calculation of free energy changes with $\mathrm{Mg}^{2+}$ ions involved. Given these potential errors in TI for $\Delta \mathrm{G}_{\text {solvation }}$ for $\mathrm{Mg}^{2+}$, the fact that we still see relatively good agreement with the ITC data for absolute binding affinity of $\mathrm{Mg}^{2+}$ helps further validate the in vitro results.

The experiments outlined above were designed with the intent to test the hypothesis that: $\mathrm{Ca}^{2+}$ and $\mathrm{Mg}^{2+}$ both interact with all the functional EF-hand motifs in cTnC. The interaction with sites III and IV has been established for some time (Johnson, Collins et al. 1980), but site II may also bind $\mathrm{Mg}^{2+}$. Interestingly, a hypothesis that is reconcilable with our own was initially put forth; that of six binding sites. In this scenario there were: two $\mathrm{Ca}^{2+}$ specific sites, two $\mathrm{Mg}^{2+}$ specific sites, and two sites that can bind both cations. During these experiments, only the absence of $\mathrm{Mg}^{2+}$ allowed for the binding sites in cTnC to be separated into low affinity sites $\left(\sim 10^{5} \mathrm{M}^{-1}\right)$ and high affinity sites $\left(\sim 10^{7} \mathrm{M}^{-1}\right)$ (Potter and Gergely 1975).

Binding of $\mathrm{Mg}^{2+}$ to site II is not expected to induce significant structural changes in $\mathrm{N}$-cTnC based on previous Molecular Dynamics simulation data (Spyracopoulos, Li et al. 1997, Skowronsky, Schroeter et al. 2013, Stevens, Rayani et al. 2017). Therefore, it is likely that the favorable $\Delta S$ associated with the interaction is due to increased degrees of freedom for the water molecules that would result when stabilizing hydrogen bonds are transferred from the positively charged metal cation and the negatively charged amino acid side chains in the binding site II to the buffered environment (Skowronsky, Schroeter et al. 2013).

Given that the binding of $\mathrm{Ca}^{2+}$ to site II of cTnC at systolic $\mathrm{Ca}^{2+}$ levels $(0.5-1.2 \mu \mathrm{M})$ strengthens the interaction with cTnl and the rest of the cTn complex and the orders of magnitude difference between binding affinity at varying levels of filament complexity, (Potter and Gergely 1975, Ramos 1999, Pinto, Parvatiyar et al. 2009, Li, Stevens et al. 2013), care must be taken when translating observations at the level of cTnC to more complex systems. Moreover, a further limitation is part of our approach which utilizes the double mutant D67A/D73A. This mutation was able to reduce the binding of both $\mathrm{Ca}^{2+}\left(11.9\right.$-fold) and $\mathrm{Mg}^{2+}(1.8$-fold) to site II of $\mathrm{N}$-cTnC; however, the impact on binding might be expected to be greater. It is possible that the effect of this double mutant is to reduce the binding of these cations, especially $\mathrm{Mg}^{2+}$ through allosteric interactions. In CaM, mutation of $\mathrm{Ca}^{2+}$ coordinating residues within the EF-hand can have structural consequences leading to altered binding kinetics (Wang, Brohus et al. 2020); this is conceivable in our double mutant. Similarily, it is possible that the competition observed between $\mathrm{Ca}^{2+}$ and $\mathrm{Mg}^{2+}$ for binding to site II of cTnC occurs through structural perturbations which follow binding of $\mathrm{Mg}^{2+}$ to an allosteric site. Exploration of these limitations in furture studies may shed light on the true nature of these interactions. 
Our ITC results strongly suggest that $\mathrm{Mg}^{2+}$ binds to site III/IV and also competes with $\mathrm{Ca}^{2+}$ for binding to site II. The amount of $\mathrm{Mg}^{2+}$ that binds the regulatory site II is likely to be highly dependent on technique, biological system, and buffer conditions. In $\mathrm{N}-\mathrm{cTnC}$, occupation of site II by $\mathrm{Mg}^{2+}$ was again seen to reduce the amount of $\mathrm{Ca}^{2+}$ which was able to bind this protein, at concentrations that may have physiologically relevant consequences under normal conditions and even more so in the face of diseases which alter the $\mathrm{Ca}^{2+}$ sensitivity of contraction.

Moreover, increases in cAMP in the cell through $\alpha$ - and $\beta$-adrenergic stimulation elicits extrusion of $\mathrm{Mg}^{2+}$ from the cell in mammalian tissues (Wolf, Di Francesco et al. 1996, Fagan and Romani 2001, Cefaratti and Romani 2007) including cardiomyocytes (Vormann and Günther 1987, Howarth, Waring et al. 1994). If shown in the heart, both $\mathrm{Na}^{+}$-dependent and independent removal of $\mathrm{Mg}^{2+}$ from the cytosol under stressful conditions would lower cytosolic presence of this cation. Despite this, free $\mathrm{Mg}^{2+}$ does not fluctuate greatly under such stimulation, suggesting that buffered $\mathrm{Mg}^{2+}$ is removed from the cell (Amano, Matsubara et al. 2000). Nevertheless, this altered $\mathrm{Mg}^{2+}$ pool may affect the subset of ions available to compete with $\mathrm{Ca}^{2+}$ for binding to troponin.

Based on our binding experiments and given the previous studies cited herein, $\mathrm{Mg}^{2+}$ may also compete with $\mathrm{Ca}^{2+}$ in binding to the regulatory site II. Free $\mathrm{Ca}^{2+}$ is tightly regulated at rest $(\sim 0.1 \mu \mathrm{M})$ despite relatively high total cytosolic concentrations $(2.1-2.6 \mathrm{mM})$ (Brini, Cali et al. 2012). $\mathrm{Mg}^{2+}$ is also abundant in the cell but is less tightly controlled. Binding of both $\mathrm{Ca}^{2+}$ and $\mathrm{Mg}^{2+}$ to site II is enothermic, and thus driven by entropy. Relative to $\mathrm{Ca}^{2+}, \mathrm{Mg}^{2+}$ binds site II with lower affinity, however at physiological concentrations or elevation of free $\mathrm{Mg}^{2+}$, which accompanies states of energy depletion, it may reduce $\mathrm{Ca}^{2+}$ binding leading to structural perturbations that modify the contractile function of the myofilament. Conversely, $\mathrm{Mg}^{2+}$ can be altered by diseased states such as secondary hyperparathyroidism which results in hypomagnesia and could potentially impact cardiac contractility (Morsy, Dishmon et al. 2017).

\section{Conclusions}

Our studies provide insights regarding the thermodynamics of metal cation binding to cTnC. The interaction of $\mathrm{Ca}^{2+}$ and $\mathrm{Mg}^{2+}$ with $\mathrm{cTnC}$ are characterized by differences consistent with dissimilar ionic radius, number of required coordinating residues, as well as the energic cost of exposing hydrophobicity amino acids to an aqueous environment. In the cell, these differences are functionally necessitated by dissimilar cytosolic prevalence of each cation. Cellular $\mathrm{Mg}^{2+}$ is not necessarily prevalent enough to directly regulate contraction and is not thought to cause a conformational change upon binding to cTnC. However, given the affinites we have observed, its occupation of the binding site may restrict $\mathrm{Ca}^{2+}$ binding. This competition for binding likely favors $\mathrm{Ca}^{2+}$ and is well tolerated, 
bioRxiv preprint doi: https://doi.org/10.1101/2020.06.14.150854; this version posted June 15, 2020. The copyright holder for this preprint (which was not certified by peer review) is the author/funder. All rights reserved. No reuse allowed without permission.

however elevation of free $\mathrm{Mg}^{2+}$, which may accompany states of ATP depletion could have relatively significant functional consequence for cardiac force production, for example during ischemic stresses. 


\section{Supplementary Appendix}

\begin{tabular}{|c|c|c|c|c|c|c|c|c|c|c|c|c|}
\hline & $\mathbf{x}$ & & $y$ & & $\mathbf{z}$ & & & & $-x$ & & & $-\mathbf{z}$ \\
\hline Site I (29-40) & L & G & A & $\mathrm{E}$ & D & G & C & I & $\mathbf{S}$ & $\mathrm{T}$ & K & $\mathbf{E}$ \\
\hline Site II (65-76) & D & $E$ & D & $\mathrm{G}$ & S & G & $\mathbf{T}$ & V & $\mathrm{D}$ & $\mathrm{F}$ & $\mathrm{D}$ & $\mathbf{E}$ \\
\hline Site III (105-116) & D & K & $\mathbf{N}$ & A & D & G & $Y$ & I & $\mathrm{D}$ & $\mathrm{L}$ & $\mathrm{D}$ & $\mathbf{E}$ \\
\hline Site IV (141-152) & $\mathrm{D}$ & K & $\mathbf{N}$ & $\mathrm{N}$ & D & G & $\mathbf{R}$ & I & $\mathrm{D}$ & $\mathrm{Y}$ & $\mathrm{D}$ & $\mathbf{E}$ \\
\hline
\end{tabular}

Figure S1 - Sequence alignment of the 4 EF hand binding motifs in cTnC

The coordinating residues within EF hands I-IV are shown with the residue number listed in brackets. Each of residues $x, y, z,-y,-x$, and $-z$, that make up the helices of the pentagonal bipyramid are indicated. The conservation of the amino acids in each of the coordinating residues between sites II, III, and IV is striking as is the clear differences seen in site I. 


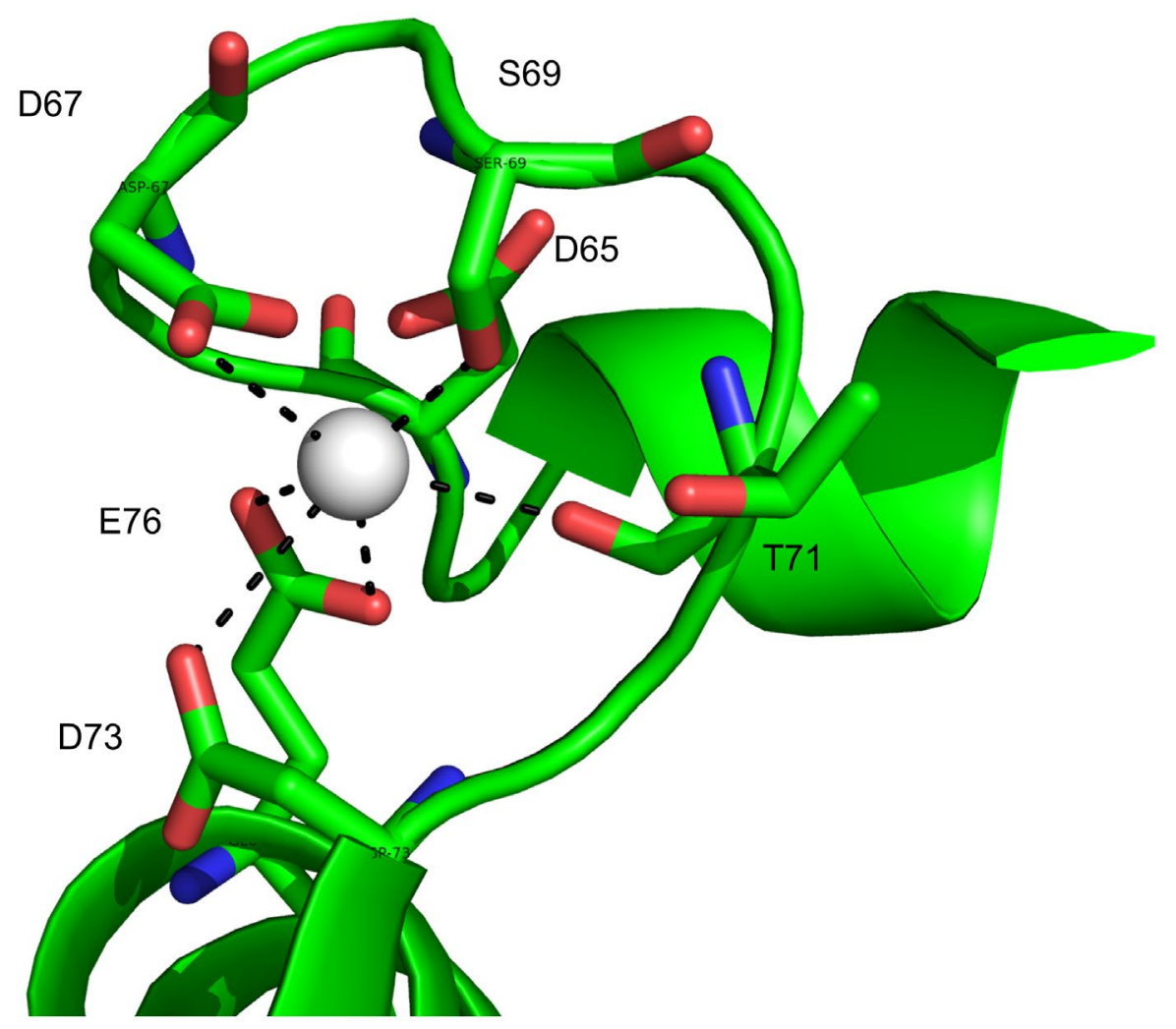

Figure S2 - Depiction of site II of WT cTnC coordinating a divalent cation

The D67A/D73A double mutant removes two of the coordinating residues within the EF hand of site II in N-cTnC. The goal of this double mutation was to compare the reduced amount of binding of $\mathrm{Ca}^{2+}$ and $\mathrm{Mg}^{2+}$ and to gain insight into the locus of binding for each cation. The figure was generated using PyMOL and adapted from the PDB:1J1E x-ray structure. 
Table S1 - Ion restraints used for thermodynamic integration

\begin{tabular}{|c|c|c|c|c|c|c|c|c|}
\hline System & \multicolumn{2}{|c|}{$\mathrm{Ca}^{2+}$ to WT N-cTnC } & \multicolumn{2}{|c|}{$\begin{array}{c}\mathrm{Ca}^{2+} \text { to D67AVD73A N- } \\
\text { cTnC }\end{array}$} & \multicolumn{2}{|c|}{$\mathrm{Mg}^{2+}$ to WT N-cTnC } & \multicolumn{2}{|c|}{$\begin{array}{c}\mathrm{Mg}^{2+} \text { to D67A/D73A N- } \\
\text { cTnC }\end{array}$} \\
\hline Restraint 1 & ASP67 CG & $2.7 \AA$ & ALA67 CB & $4.2 \AA$ & ASP67 CG & $2.3 \AA$ & THR71 O & $1.9 \AA$ \\
\hline Restraint 2 & SER69 OG & $2.6 \AA$ & SER69 OG & $2.6 \AA$ & SER69 OG & $3.7 \AA$ & SER69 OG & $2.0 \AA$ \\
\hline Restraint 3 & GLU76 CD & $2.8 \AA$ & GLU76 CD & $2.8 \AA$ & THR71 OG1 & $4.5 \AA$ & ASP65 CG & $2.3 \AA$ \\
\hline
\end{tabular}

For each system, 3 restraints to the ion were used. Table shows atom and distance to restrained ion. 
Table S2 - Thermodynamic Parameters for $\mathrm{Ca}^{2+}$ and $\mathrm{Mg}^{2+}$ binding to $\mathrm{N}-\mathrm{cTnC}$

\begin{tabular}{|c|c|c|c|c|c|c|c|c|}
\hline Titrant & $\begin{array}{l}\mathrm{N}-\mathrm{cTnC} \\
\text { Condition }\end{array}$ & $\mathbf{n}$ & $\mathbf{N}$ & $\begin{array}{c}K_{A}^{*} \mathbf{1 0}^{3} \\
\left(M^{-1}\right)\end{array}$ & $\begin{array}{c}\mathbf{K}_{\mathbf{d}} \\
(\mu \mathrm{M})\end{array}$ & $\underset{\left(\mathrm{kcal}^{*} \mathrm{~mol}^{-1}\right)}{\boldsymbol{\Delta H}}$ & $\underset{\left(\mathrm{kcal}^{*} \mathrm{~mol}^{-1}\right)}{\mathbf{T}^{*} \boldsymbol{\Delta}}$ & $\underset{\left(\left.\mathrm{kcal}\right|^{*} \mathrm{~mol}^{-1}\right)}{\boldsymbol{\Delta G}}$ \\
\hline \multirow{7}{*}{$\mathrm{Ca}^{2+}$} & Apo-State & 7 & $\begin{array}{c}1.01 \pm \\
0.01\end{array}$ & $\begin{array}{c}66.1^{\mathrm{A}} \\
\pm 2.0^{-} \\
\end{array}$ & $\begin{array}{c}15.2^{C} \\
\pm 0.5\end{array}$ & $\begin{array}{c}3.82^{\mathrm{A}} \\
\pm 0.04 \\
\end{array}$ & $\begin{array}{c}10.39^{\mathrm{A}} \\
\pm 0.03 \\
\end{array}$ & $\begin{array}{c}-6.57^{\mathrm{H}} \\
\pm 0.02 \\
\end{array}$ \\
\hline & D67A/D73A & 8 & 1.00 & $\begin{array}{c}5.9^{\mathrm{E}, \mathrm{F}} \\
\pm 0.5\end{array}$ & $\begin{array}{c}180.3^{C} \\
\pm 16.2^{C} \\
\end{array}$ & $\begin{array}{c}0.23^{\mathrm{H}, \mathrm{I}} \\
\pm 0.02 \\
\end{array}$ & $\begin{array}{c}5.36^{\mathrm{G}} \\
\pm 0.05\end{array}$ & $\begin{array}{c}-5.12^{\mathrm{D}} \\
\pm 0.05\end{array}$ \\
\hline & $+1 \mathrm{mM} \mathrm{Mg}^{2+}$ & 6 & 1.00 & $\begin{array}{c}31.2^{\mathrm{B}} \\
\pm 2.7 \\
\end{array}$ & $\begin{array}{c}33.1^{\mathrm{C}} \\
\pm 2.57 \\
\end{array}$ & $\begin{array}{c}2.47^{\mathrm{B}} \\
\pm 0.05 \\
\end{array}$ & $\begin{array}{c}8.58^{\mathrm{B}} \\
\pm 0.01 \\
\end{array}$ & $\begin{array}{c}-6.12^{G} \\
\pm 0.05 \\
\end{array}$ \\
\hline & $+3 \mathrm{mM} \mathrm{Mg}^{2+}$ & 7 & 1.00 & $\begin{array}{c}20.9^{C} \\
\pm 1.3 \\
\end{array}$ & $\begin{array}{c}48.9^{\mathrm{C}} \\
\pm 2.81 \\
\end{array}$ & $\begin{array}{l}1.73^{\mathrm{C}} \\
\pm 0.05\end{array}$ & $\begin{array}{c}7.62^{C} \\
\pm 0.03 \\
\end{array}$ & $\begin{array}{c}-5.89^{G} \\
\pm 0.04\end{array}$ \\
\hline & $+5 \mathrm{mM} \mathrm{Mg}^{2+}$ & 7 & 1.00 & $\begin{array}{c}14.0^{\mathrm{D}} \\
\pm 0.7\end{array}$ & $\begin{array}{c}72.3^{\mathrm{C}} \\
\pm 3.17 \\
\end{array}$ & $\begin{array}{l}1.52^{\mathrm{D}} \\
\pm 0.05\end{array}$ & $\begin{array}{c}7.17^{\mathrm{D}} \\
\pm 0.04\end{array}$ & $\begin{array}{c}-5.65^{\mathrm{F}} \\
\pm 0.02 \\
\end{array}$ \\
\hline & $+10 \mathrm{mM} \mathrm{Mg}{ }^{2+}$ & 7 & 1.00 & $\begin{array}{c}9.7^{\mathrm{D}, \mathrm{E}} \\
\pm 0.5\end{array}$ & $\begin{array}{c}105.3^{C} \\
\pm 5.54\end{array}$ & $\begin{array}{l}1.13^{\mathrm{E}} \\
\pm 0.04 \\
\end{array}$ & $\begin{array}{c}6.57^{\mathrm{E}} \\
\pm 0.02 \\
\end{array}$ & $\begin{array}{c}-5.43^{E, F} \\
\pm 0.03\end{array}$ \\
\hline & $+20 \mathrm{mM} \mathrm{Mg}^{2+}$ & 5 & 1.00 & $\begin{array}{c}8.2^{\mathrm{E}} \\
\pm 0.1 \\
\end{array}$ & $\begin{array}{c}122.8^{\mathrm{C}} \\
\pm 2.06 \\
\end{array}$ & $\begin{array}{c}0.78^{F} \\
\pm 0.04 \\
\end{array}$ & $\begin{array}{c}6.13^{F} \\
\pm 0.03 \\
\end{array}$ & $\begin{array}{c}-5.35^{\mathrm{D}, \mathrm{E}} \\
\pm 0.01 \\
\end{array}$ \\
\hline \multirow{6}{*}{$\mathrm{Mg}^{2+}$} & Apo-State & 5 & 1.00 & $\begin{array}{c}1.54^{F, G} \\
\pm 0.06\end{array}$ & $\begin{array}{c}652.8^{\mathrm{B}, \mathrm{C}} \\
\pm 28.4\end{array}$ & $\begin{array}{c}2.64^{\mathrm{B}} \\
\pm 0.1\end{array}$ & $\begin{array}{c}6.99^{\mathrm{D}} \\
\pm 0.07\end{array}$ & $\begin{array}{c}-4.35^{\mathrm{C}} \\
\pm 0.03\end{array}$ \\
\hline & D67A/D73A & 5 & 1.00 & $\begin{array}{c}0.90^{\mathrm{F}, \mathrm{G}} \\
\pm 0.08\end{array}$ & $\begin{array}{c}1148.6^{\mathrm{A}} \\
\pm 95.0\end{array}$ & $\begin{array}{c}0.76^{\mathrm{F}} \\
\pm 0.04 \\
\end{array}$ & $\begin{array}{c}4.78^{\mathrm{H}} \\
\pm 0.03\end{array}$ & $\begin{array}{c}-4.02^{\mathrm{B}} \\
\pm 0.05 \\
\end{array}$ \\
\hline & $+1 \mathrm{mM} \mathrm{Ca}^{2+}$ & 5 & 1.00 & $\begin{array}{c}0.55^{G} \\
\pm 0.05\end{array}$ & $\begin{array}{c}1870.0^{\mathrm{A}} \\
\pm 171.5\end{array}$ & $\begin{array}{c}0.48^{\mathrm{G}} \\
\pm 0.04\end{array}$ & $\begin{array}{c}4.22 \\
\pm 0.03 \\
\end{array}$ & $\begin{array}{c}-3.73^{A} \\
\pm 0.05 \\
\end{array}$ \\
\hline & $+2 \mathrm{mM} \mathrm{Ca}^{2+}$ & 6 & 1.00 & $\begin{array}{c}0.47^{\mathrm{G}} \\
\pm 0.05\end{array}$ & $\begin{array}{c}2251.7^{\mathrm{A}} \\
\pm 261.8 \\
\end{array}$ & $\begin{array}{c}0.41^{\mathrm{G}, \mathrm{H}} \\
\pm 0.04\end{array}$ & $\begin{array}{c}4.04^{\mathrm{I}, \mathrm{J}} \\
\pm 0.07 \\
\end{array}$ & $\begin{array}{c}-3.63^{\mathrm{A}} \\
\pm 0.07 \\
\end{array}$ \\
\hline & $+3 \mathrm{mM} \mathrm{Ca}^{2+}$ & 8 & 1.00 & $\begin{array}{c}0.52^{G} \\
\pm 0.04\end{array}$ & $\begin{array}{c}2037.5^{\mathrm{A}} \\
\pm 172.2^{2}\end{array}$ & $\begin{array}{c}0.24^{\mathrm{H}, \mathrm{I}} \\
\pm 0.02\end{array}$ & $\begin{array}{l}3.92^{\mathrm{J}} \\
\pm 0.04\end{array}$ & $\begin{array}{c}-3.69^{\mathrm{A}} \\
\pm 0.05\end{array}$ \\
\hline & $+5 \mathrm{mM} \mathrm{Ca}^{2+}$ & 9 & 1.00 & $\begin{array}{c}0.50^{G} \\
\pm 0.08\end{array}$ & $\begin{array}{c}2255.8^{\mathrm{A}} \\
\pm 220.1 \\
\end{array}$ & $\begin{array}{c}0.20^{1} \\
\pm 0.02 \\
\end{array}$ & $\begin{array}{c}3.84^{\mathrm{J}} \\
\pm 0.06 \\
\end{array}$ & $\begin{array}{c}-3.64^{\mathrm{A}} \\
\pm 0.07 \\
\end{array}$ \\
\hline
\end{tabular}

In this figure, $\mathrm{n}$ indicates the experimental repeats and $\mathrm{N}$ indicates the stoichiometry number. $4 \mathrm{mM} \mathrm{Ca}{ }^{2+}$ and $20 \mathrm{mM} \mathrm{Mg}^{2+}$ titrations into $200 \mu \mathrm{M} \mathrm{N}-\mathrm{cTnC}$ were the baseline conditions. For the $\mathrm{Ca}^{2+}$ titrations, pre-incubation with 1, 3, 5, 10, and $20 \mathrm{mM} \mathrm{Mg}^{2+}$ prior to titrations was used to study the site II occupation by both cations. The affinity and enthalpy change associated with the interaction was decreased with increasing amounts of $\mathrm{Mg}^{2+}$ incubated. For the $\mathrm{Mg}^{2+}$ titrations, pre-incubation with 1, 2, 3, $5 \mathrm{mM} \mathrm{Ca}^{2+}$ prior to titrations was used to study the binding of both cations to site II. Increasing the concentration of $\mathrm{Ca}^{2+}$ decreased the binding affinity of $\mathrm{Mg}^{2+}$ to site $\mathrm{II}$ and decreased the enthalpy change, therefore less $\mathrm{Mg}^{2+}$ binds $\mathrm{N}-\mathrm{cTnC}$ in the presence of $\mathrm{Ca}^{2+}$. The D67A/D73A mutant was used to reduce the binding of both cations to the EF hand of site II, albeit to a different extent for each. All parameters are displayed as mean \pm SEM, with the exception of the stoichiometric ratio for the $\mathrm{Mg}^{2+}$ binding which was constrained to 1.00 to facilitate fitting. Titrations not linked with the same superscripted letter were significantly different $(p<0.05)$. The first letter of the alphabet indicates the largest mean and each subsequent letter denotes a significantly lower mean. 
Table S3 - Thermodynamic Parameters for $\mathrm{Ca}^{2+}$ and $\mathrm{Mg}^{2+}$ binding to full-length $\mathrm{cTnC}$

\begin{tabular}{|c|c|c|c|c|c|c|c|c|c|}
\hline & Titrant & $\begin{array}{c}\text { cTnC } \\
\text { condition }\end{array}$ & $\mathbf{n}$ & $\mathbf{N}$ & $\underset{{ }^{*} 10^{3}\left(\mathrm{M}^{-1}\right)}{\mathbf{K}_{\mathbf{A}}}$ & $\begin{array}{c}\mathbf{K}_{\mathbf{d}} \\
(\mu \mathrm{M})\end{array}$ & $\underset{\left(\mathrm{kcal}^{*} \mathrm{~mol}^{-1}\right)}{\Delta \mathbf{H}}$ & $\underset{\left(\mathrm{kcal}^{*} \mathrm{~mol}^{-1}\right)}{\mathbf{T}^{*} \boldsymbol{\Delta}}$ & $\underset{\left(\mathrm{kcal}{ }^{*} \mathrm{~mol}^{-1}\right)}{\boldsymbol{\Delta} \mathbf{G}}$ \\
\hline \multirow{4}{*}{$\begin{array}{l}\text { Site } \\
\text { II }\end{array}$} & $\mathrm{Ca}^{2+}$ & Apo-State & 7 & $\begin{array}{l}1.91 \\
\pm 0.07 \\
\end{array}$ & $\begin{array}{c}44.3^{\mathrm{A}} \\
\pm 1.0 \\
\end{array}$ & $\begin{array}{c}22.7^{B} \\
\pm 0.5 \\
\end{array}$ & $\begin{array}{c}3.71 \mathrm{~A} \\
\pm 0.06\end{array}$ & $\begin{array}{c}10.0^{\mathrm{A}} \\
\pm 0.07\end{array}$ & $\begin{array}{c}-6.29 \mathrm{C} \\
\pm 0.20\end{array}$ \\
\hline & $\mathbf{M g}^{2+}$ & Apo-State & 8 & $\begin{array}{l}32.9 \\
\pm 0.5 \\
\end{array}$ & $\begin{array}{c}2.47^{\mathrm{C}} \\
\pm 0.05 \\
\end{array}$ & $\begin{array}{c}406.1 \mathrm{~A} \\
\pm 7.9 \\
\end{array}$ & $\begin{array}{c}0.091^{D} \\
\pm 0.001 \\
\end{array}$ & $\begin{array}{c}4.71 \mathrm{D} \\
\pm 0.01 \\
\end{array}$ & $\begin{array}{c}-4.62 \mathrm{~A} \\
\pm 0.11 \\
\end{array}$ \\
\hline & $\mathrm{Ca}^{2+}$ & $+1 \mathrm{mM} \mathrm{Mg}^{2+}$ & 8 & $\begin{array}{l}2.10 \\
\pm 0.05\end{array}$ & $\begin{array}{c}32.4 \mathrm{~B} \\
\pm 0.9\end{array}$ & $\begin{array}{c}31.0 \mathrm{~B} \\
\pm 0.9\end{array}$ & $\begin{array}{l}1.93 \mathrm{~B} \\
\pm 0.09\end{array}$ & $\begin{array}{l}8.09 \mathrm{~B} \\
\pm 0.08\end{array}$ & $\begin{array}{c}-6.16 \mathrm{~B} \\
\pm 0.59\end{array}$ \\
\hline & $\mathrm{Ca}^{2+}$ & $+3 \mathrm{mM} \mathrm{Mg}^{2+}$ & 10 & $\begin{array}{l}2.96 \\
\pm 0.06 \\
\end{array}$ & $\begin{array}{c}29.1 \mathrm{~B} \\
\pm 1.7 \\
\end{array}$ & $\begin{array}{c}35.5^{\mathrm{B}} \\
\pm 2.1 \\
\end{array}$ & $\begin{array}{c}0.75^{\mathrm{C}} \\
\pm 0.03 \\
\end{array}$ & $\begin{array}{l}6.83 \mathrm{C} \\
\pm 0.04 \\
\end{array}$ & $\begin{array}{c}-6.08 \mathrm{~B}^{\mathrm{B}} \\
\pm 0.54 \\
\end{array}$ \\
\hline \multirow{4}{*}{$\begin{array}{l}\text { Sites } \\
\text { III/IV }\end{array}$} & $\mathrm{Ca}^{2+}$ & Apo-State & 7 & $\begin{array}{l}2.19 \\
\pm 0.05 \\
\end{array}$ & $\begin{array}{c}8757.1 \text { B } \\
\pm 951.4 \\
\end{array}$ & $\begin{array}{c}0.12 \mathrm{~B} \\
\pm 0.02 \\
\end{array}$ & $\begin{array}{c}-8.20 \mathrm{D} \\
\pm 0.07 \\
\end{array}$ & $\begin{array}{c}1.24 \mathrm{D} \\
\pm 0.07 \\
\end{array}$ & $\begin{array}{c}-9.44 \text { B } \\
\pm 0.61 \\
\end{array}$ \\
\hline & $\mathbf{M g}^{2+}$ & Apo-State & 8 & $\begin{array}{l}4.92 \\
\pm 0.15 \\
\end{array}$ & $\begin{array}{c}60.5^{\mathrm{C}} \\
\pm 3.0 \\
\end{array}$ & $\begin{array}{c}16.7^{\mathrm{A}} \\
\pm 0.7 \\
\end{array}$ & $\begin{array}{c}-0.23 \mathrm{~A} \\
\pm 0.01 \\
\end{array}$ & $\begin{array}{l}6.28 \mathrm{~A} \\
\pm 0.03 \\
\end{array}$ & $\begin{array}{c}-6.51 \mathrm{~A} \\
\pm 0.31 \\
\end{array}$ \\
\hline & $\mathrm{Ca}^{2+}$ & $+1 \mathrm{mM} \mathrm{Mg}^{2+}$ & 8 & $\begin{array}{l}2.02 \\
\pm 0.04 \\
\end{array}$ & $\begin{array}{c}7526.3^{B} \\
\pm 333.5 \\
\end{array}$ & $\begin{array}{c}0.14 \mathrm{~B} \\
\pm 0.01 \\
\end{array}$ & $\begin{array}{l}-6.87^{C} \\
\pm 0.09 \\
\end{array}$ & $\begin{array}{c}2.50 \mathrm{C} \\
\pm 0.10 \\
\end{array}$ & $\begin{array}{c}-9.37 \text { B } \\
\pm 0.50 \\
\end{array}$ \\
\hline & $\mathrm{Ca}^{2+}$ & $+3 \mathrm{mM} \mathrm{Mg}^{2+}$ & 10 & $\begin{array}{l}1.94 \\
\pm 0.04\end{array}$ & $\begin{array}{c}12870.0^{\mathrm{A}} \\
\pm 939.6\end{array}$ & $\begin{array}{c}0.08 \mathrm{~B} \\
\pm 0.01\end{array}$ & $\begin{array}{c}-6.19 \mathrm{~B} \\
\pm 0.06\end{array}$ & $\begin{array}{c}3.50 \mathrm{~B} \\
\pm 0.06\end{array}$ & $\begin{array}{c}-9.79 \mathrm{C} \\
\pm 0.26\end{array}$ \\
\hline
\end{tabular}

In this figure, $\mathrm{n}$ indicates the experimental repeats and $\mathrm{N}$ indicates the stoichiometry number. $6 \mathrm{mM} \mathrm{Ca}{ }^{2+}$ and $40 \mathrm{mM} \mathrm{Mg}^{2+}$ titrations into $100 \mu \mathrm{M} \mathrm{N}-c T n C$ were the baseline conditions. $\mathrm{Ca}^{2+}$ was also titrated into protein pre-incubated with 1 and $3 \mathrm{mM} \mathrm{Mg}{ }^{2+}$ to study the competition for all three binding sites. Binding to site II was analyzed separately from binding to sites IIII/IV where analysis of variance was used to test for a significant difference in the means for each thermodynamic parameter. At the level of each parameter, Tukey's post hoc test was carried out. The results of this test are indicated by superscripted letters, where conditions with unique letters are significantly different $(p<0.05)$. 


\section{References}

Allen, K., Y. Y. Xu and W. G. Kerrick (2000). "Ca2+measurements in skinned cardiac fibers: effects of Mg2+ on Ca2+ activation of force and fiber ATPase." J Appl Physiol (1985) 88(1): 180-185.

Allen, T. S., L. D. Yates and A. M. Gordon (1992). "Ca2+-dependence of structural changes in troponin$\mathrm{C}$ in demembranated fibers of rabbit psoas muscle." Biophys J 61(2): 399-409.

Amano, T., T. Matsubara, J. Watanabe, S. Nakayama and N. Hotta (2000). "Insulin modulation of intracellular free magnesium in heart: involvement of protein kinase C." British journal of pharmacology 130(4): 731-738.

Àqvist, J. (1990). "Ion-water interaction potentials derived from free energy perturbation simulations." The Journal of Physical Chemistry 94(21): 8021-8024.

Ashley, C. C. and D. G. Moisescu (1977). "Effect of changing the composition of the bathing solutions upon the isometric tension-pCa relationship in bundles of crustacean myofibrils." J Physiol 270(3): 627-652.

Bers, D. M. (2000). "Calcium Fluxes Involved in Control of Cardiac Myocyte Contraction." Circulation Research 87(4): 275-281.

Best, P. M., S. K. Donaldson and W. G. Kerrick (1977). "Tension in mechanically disrupted mammalian cardiac cells: effects of magnesium adenosine triphosphate." J Physiol 265(1): 1-17.

Boresch, S., F. Tettinger, M. Leitgeb and M. Karplus (2003). "Absolute Binding Free Energies: A Quantitative Approach for Their Calculation." The Journal of Physical Chemistry B 107(35): 95359551.

Bowman, J. D. and S. Lindert (2018). "Molecular Dynamics and Umbrella Sampling Simulations Elucidate Differences in Troponin C Isoform and Mutant Hydrophobic Patch Exposure." 122(32): 7874-7883.

Brini, M., T. Cali, D. Ottolini and E. Carafoli (2012). "Calcium pumps: why so many?" Compr Physiol 2(2): 1045-1060.

Carafoli, E. and J. Krebs (2016). "Why Calcium? How Calcium Became the Best Communicator." $\underline{\text { J Biol }}$ Chem 291(40): 20849-20857.

Cates, M. S., M. B. Berry, E. L. Ho, Q. Li, J. D. Potter and G. N. Phillips, Jr. (1999). "Metal-ion affinity and specificity in EF-hand proteins: coordination geometry and domain plasticity in parvalbumin." Structure 7(10): 1269-1278.

Cefaratti, C. and A. M. Romani (2007). "Functional characterization of two distinct Mg 2+ extrusion mechanisms in cardiac sarcolemmal vesicles." Molecular and cellular biochemistry 303(1-2): 6372.

Chao, S. H., Y. Suzuki, J. R. Zysk and W. Y. Cheung (1984). "Activation of calmodulin by various metal cations as a function of ionic radius." Mol Pharmacol 26(1): 75-82.

Cheung, J. Y., D. L. Tillotson, R. Yelamarty and R. Scaduto (1989). "Cytosolic free calcium concentration in individual cardiac myocytes in primary culture." American Journal of Physiology-Cell Physiology 256(6): C1120-C1130.

Dai, L. J., P. A. Friedman and G. A. Quamme (1997). "Cellular mechanisms of chlorothiazide and cellular potassium depletion on Mg2+ uptake in mouse distal convoluted tubule cells." Kidney Int 51(4): 1008-1017. 
Davis, J. P., J. A. Rall, P. J. Reiser, L. B. Smillie and S. B. Tikunova (2002). "Engineering competitive magnesium binding into the first EF-hand of skeletal troponin C." J Biol Chem 277(51): 4971649726.

Dokmanic, I., M. Sikic and S. Tomic (2008). "Metals in proteins: correlation between the metal-ion type, coordination number and the amino-acid residues involved in the coordination." Acta Crystallogr D Biol Crystallogr 64(Pt 3): 257-263.

Donaldson, S. K., P. M. Best and G. L. Kerrick (1978). "Characterization of the effects of Mg2+ on Ca2+and Sr2+-activated tension generation of skinned rat cardiac fibers." J Gen Physiol 71(6): 645655.

Donaldson, S. K. and W. G. Kerrick (1975). "Characterization of the effects of Mg2+ on Ca2+- and Sr2+activated tension generation of skinned skeletal muscle fibers." J Gen Physiol 66(4): 427-444.

Ebashi, S. and M. Endo (1968). "Calcium ion and muscle contraction." Prog Biophys Mol Biol 18: 123183.

Ebashi, S., Y. Nonomura, K. Kohama, T. Kitazawa and T. Mikawa (1980). "Regulation of muscle contraction by Ca ion." Mol Biol Biochem Biophys 32: 183-194.

Ebashi, S. and Y. Ogawa (1988). "Ca2+ in contractile processes." Biophys Chem 29(1-2): 137-143.

Fabiato, A. and F. Fabiato (1975). "Effects of magnesium on contractile activation of skinned cardiac cells." J Physiol 249(3): 497-517.

Fagan, T. E. and A. Romani (2001). "a1-Adrenoceptor-induced Mg2+ extrusion from rat hepatocytes occurs via Na+-dependent transport mechanism." American Journal of PhysiologyGastrointestinal and Liver Physiology 280(6): G1145-G1156.

Farah, C. S. and F. C. Reinach (1995). "The troponin complex and regulation of muscle contraction." Faseb i 9(9): 755-767.

Filatov, V. L., A. G. Katrukha, T. V. Bulargina and N. B. Gusev (1999). "Troponin: structure, properties, and mechanism of functioning." Biochemistry (Mosc) 64(9): 969-985.

Follenius, A. and D. Gerard (1984). "Fluorescence investigations of calmodulin hydrophobic sites." Biochem Biophys Res Commun 119(3): 1154-1160.

Francois, J. M., C. Gerday, F. G. Prendergast and J. D. Potter (1993). "Determination of the Ca2+ and $\mathrm{Mg} 2+$ affinity constants of troponin $\mathrm{C}$ from eel skeletal muscle and positioning of the single tryptophan in the primary structure." J Muscle Res Cell Motil 14(6): 585-593.

Gifford, Jessica L., Michael P. Walsh and Hans J. Vogel (2007). "Structures and metal-ion-binding properties of the Ca<sup $>2+</$ sup $>$-binding helix-loop-helix EF-hand motifs." Biochemical Journal 405(2): 199-221.

Gilli, R., D. Lafitte, C. Lopez, M. Kilhoffer, A. Makarov, C. Briand and J. Haiech (1998). "Thermodynamic analysis of calcium and magnesium binding to calmodulin." Biochemistry 37(16): 5450-5456.

Gillis, T. E., T. M. Blumenschein, B. D. Sykes and G. F. Tibbits (2003). "Effect of temperature and the F27W mutation on the Ca2+ activated structural transition of trout cardiac troponin C." Biochemistry 42(21): 6418-6426.

Gillis, T. E., C. R. Marshall, X.-H. Xue, T. J. Borgford and G. F. Tibbits (2000). "Ca2+ binding to cardiac troponin $\mathrm{C}$ : effects of temperature and $\mathrm{pH}$ on mammalian and salmonid isoforms." American Journal of Physiology-Regulatory, Integrative and Comparative Physiology 279(5): R1707-R1715.

Gillis, T. E., C. D. Moyes and G. F. Tibbits (2003). "Sequence mutations in teleost cardiac troponin C that are permissive of high $\mathrm{Ca} 2+$ affinity of site II." American Journal of Physiology-Cell Physiology 284(5): C1176-C1184. 
Godt, R. E. (1974). "Calcium-activated tension of skinned muscle fibers of the frog. Dependence on magnesium adenosine triphosphate concentration." J Gen Physiol 63(6): 722-739.

Godt, R. E. and B. D. Lindley (1982). "Influence of temperature upon contractile activation and isometric

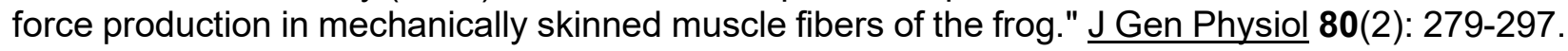

Godt, R. E. and J. L. Morgan (1984). "Contractile responses to MgATP and pH in a thick filament regulated muscle: studies with skinned scallop fibers." Adv Exp Med Biol 170: 569-572.

Grossoehme, N. E., A. M. Spuches and D. E. Wilcox (2010). "Application of isothermal titration calorimetry in bioinorganic chemistry." J Biol Inorg Chem 15(8): 1183-1191.

Harding, M. M. (2002). "Metal-ligand geometry relevant to proteins and in proteins: sodium and potassium." Acta Crystallogr D Biol Crystallogr 58(Pt 5): 872-874.

Hazard, A. L., S. C. Kohout, N. L. Stricker, J. A. Putkey and J. J. Falke (1998). "The kinetic cycle of cardiac troponin $\mathrm{C}$ : calcium binding and dissociation at site II trigger slow conformational rearrangements." Protein Science 7(11): 2451-2459.

Herzberg, O. and M. N. James (1985). "Structure of the calcium regulatory muscle protein troponin-C at 2.8 Å resolution."

Holroyde, M., S. Robertson, J. Johnson, R. Solaro and J. Potter (1980). "The calcium and magnesium binding sites on cardiac troponin and their role in the regulation of myofibrillar adenosine triphosphatase." Journal of Biological Chemistry 255(24): 11688-11693.

Hongo, K., M. Konishi and S. Kurihara (1994). "Cytoplasmic free Mg2+ in rat ventricular myocytes studied with the fluorescent indicator furaptra." Jpn J Physiol 44(4): 357-378.

Houdusse, A., M. L. Love, R. Dominguez, Z. Grabarek and C. Cohen (1997). "Structures of four Ca2+bound troponin $\mathrm{C}$ at $2.0 \mathrm{~A}$ resolution: further insights into the $\mathrm{Ca} 2+$-switch in the calmodulin superfamily." Structure 5(12): 1695-1711.

Howarth, F., J. Waring, B. Hustler and J. Singh (1994). "Effects of extracellular magnesium and beta adrenergic stimulation on contractile force and magnesium mobilization in the isolated rat heart." Magnesium research 7(3-4): 187-197.

Johnson, J. D., S. C. Charlton and J. D. Potter (1979). "A fluorescence stopped flow analysis of Ca2+ exchange with troponin C." J Biol Chem 254(9): 3497-3502.

Johnson, J. D., J. H. Collins, S. P. Robertson and J. D. Potter (1980). "A fluorescent probe study of $\mathrm{Ca} 2+$ binding to the $\mathrm{Ca} 2+-$ specific sites of cardiac troponin and troponin C." Journal of Biological Chemistry 255(20): 9635-9640.

Johnson, J. D., R. J. Nakkula, C. Vasulka and L. B. Smillie (1994). "Modulation of Ca2+ exchange with the $\mathrm{Ca}(2+)$-specific regulatory sites of troponin C." J Biol Chem 269(12): 8919-8923.

Johnson, R. A., L. M. Fulcher, K. Vang, C. D. Palmer, N. E. Grossoehme and A. M. Spuches (2019). "In depth, thermodynamic analysis of $\mathrm{Ca}(2+)$ binding to human cardiac troponin $\mathrm{C}$ : Extracting bufferindependent binding parameters." Biochim Biophys Acta Proteins Proteom 1867(4): 359-366.

Kawasaki, Y. and J.-P. van Eerd (1972). "The effect of Mg++ on the conformation of the Ca++-binding component of troponin." Biochemical and Biophysical Research Communications 49(4): 898-905.

Kerrick, W. G. L. and S. K. B. Donaldson (1975). "The comparative effects of [Ca2+] and [Mg2+] on tension generation in the fibers of skinned frog skeletal muscle and mechanically disrupted rat ventricular cardiac muscle." Pflügers Archiv 358(3): 195-201.

Kirschenlohr, H. L., A. A. Grace, J. I. Vandenberg, J. C. Metcalfe and G. A. Smith (2000). "Estimation of systolic and diastolic free intracellular $\mathrm{Ca} 2+$ by titration of $\mathrm{Ca} 2+$ buffering in the ferret heart." Biochem J 346 Pt 2: 385-391. 
Kohama, K. (1980). "Role of the high affinity Ca binding sites of cardiac and fast skeletal troponins." $\underline{\mathrm{J}}$ Biochem 88(2): 591-599.

Kometani, K. and K. Yamada (1983). "Enthalpy, entropy and heat capacity changes induced by binding of calcium ions to cardiac troponin C." Biochemical and biophysical research communications 114(1): 162-167.

L DeLano, W. (2002). The PyMOL Molecular Graphics System (2002) DeLano Scientific, Palo Alto, CA, USA. http://www.pymol.org.

Laires, M. J., C. P. Monteiro and M. Bicho (2004). "Role of cellular magnesium in health and human disease." Front Biosci 9: 262-276.

Leavis, P. and E. L. Kraft (1978). "Calcium binding to cardiac troponin C." Archives of biochemistry and biophysics 186(2): 411-415.

Leelananda, S. P. and S. Lindert (2016). "Computational methods in drug discovery." Beilstein J Org Chem 12: 2694-2718.

Lewit-Bentley, A. and S. Rety (2000). "EF-hand calcium-binding proteins." Curr Opin Struct Biol 10(6): 637-643.

Li, A. Y., C. M. Stevens, B. Liang, K. Rayani, S. Little, J. Davis and G. F. Tibbits (2013). "Familial hypertrophic cardiomyopathy related cardiac troponin C L29Q mutation alters length-dependent activation and functional effects of phosphomimetic troponin $I^{*}$."

Li, M. X., M. Chandra, J. R. Pearlstone, K. I. Racher, G. Trigo-Gonzalez, T. Borgford, C. M. Kay and L. B. Smillie (1994). "Properties of isolated recombinant $\mathrm{N}$ and $\mathrm{C}$ domains of chicken troponin C." Biochemistry 33(4): 917-925.

Li, M. X., L. Spyracopoulos and B. D. Sykes (1999). "Binding of Cardiac Troponin-I147-163 Induces a Structural Opening in Human Cardiac Troponin-C." Biochemistry 38(26): 8289-8298.

Li, P., B. P. Roberts, D. K. Chakravorty and K. M. Merz, Jr. (2013). "Rational Design of Particle Mesh Ewald Compatible Lennard-Jones Parameters for +2 Metal Cations in Explicit Solvent." J Chem Theory Comput 9(6): 2733-2748.

Liang, B., F. Chung, Y. Qu, D. Pavlov, T. E. Gillis, S. B. Tikunova, J. P. Davis and G. F. Tibbits (2008). "Familial hypertrophic cardiomyopathy-related cardiac troponin C mutation L29Q affects Ca2+ binding and myofilament contractility." Physiological genomics 33(2): 257-266.

Linse, S. and S. Forsen (1995). "Determinants that govern high-affinity calcium binding." Adv Second Messenger Phosphoprotein Res 30: 89-151.

Lockless, S. W., M. Zhou and R. MacKinnon (2007). "Structural and thermodynamic properties of selective ion binding in a K+ channel." PLoS Biol 5(5): e121.

Maguire, M. E. (2006). "Magnesium transporters: properties, regulation and structure." Front Biosci 11: 3149-3163.

Maier, J. A., C. Martinez, K. Kasavajhala, L. Wickstrom, K. E. Hauser and C. Simmerling (2015). "ff14SB: Improving the Accuracy of Protein Side Chain and Backbone Parameters from ff99SB." J Chem Theory Comput 11(8): 3696-3713.

Malmendal, A., S. Linse, J. Evenas, S. Forsen and T. Drakenberg (1999). "Battle for the EF-hands: magnesium-calcium interference in calmodulin." Biochemistry 38(36): 11844-11850.

Morimoto, S. (1991). "Effect of myosin cross-bridge interaction with actin on the Ca2+-binding properties of troponin C in fast skeletal myofibrils." The Journal of Biochemistry 109(1): 120-126. 
Morsy, M. S., D. A. Dishmon, N. Garg and K. T. Weber (2017). "Secondary hyperparathyroidism in heart failure." The American journal of the medical sciences 354(4): 335-338.

Murray, A. C. and C. M. Kay (1972). "Hydrodynamic and optical properties of troponin A. Demonstration of a conformational change upon binding calcium ion." Biochemistry 11(14): 2622-2627.

Nara, M., H. Morii and M. Tanokura (2013). "Infrared study of synthetic peptide analogues of the calciumbinding site III of troponin C: The role of helix F of an EF-hand motif." Biopolymers 99(5): 342-347.

Ogawa, Y. (1985). "Calcium binding to troponin $\mathrm{C}$ and troponin: effects of $\mathrm{Mg} 2+$, ionic strength and $\mathrm{pH} . "$ The Journal of Biochemistry 97(4): 1011-1023.

Pan, B. S. and R. J. Solaro (1987). "Calcium-binding properties of troponin C in detergent-skinned heart muscle fibers." J Biol Chem 262(16): 7839-7849.

Panteva, M. T., G. M. Giambasu and D. M. York (2015). "Comparison of structural, thermodynamic, kinetic and mass transport properties of $\mathrm{Mg}(2+)$ ion models commonly used in biomolecular simulations." J Comput Chem 36(13): 970-982.

Parmacek, M. S. and R. J. Solaro (2004). "Biology of the troponin complex in cardiac myocytes." Prog Cardiovasc Dis 47(3): 159-176.

Pinto, J. R., M. S. Parvatiyar, M. A. Jones, J. Liang, M. J. Ackerman and J. D. Potter (2009). "A functional and structural study of troponin $\mathrm{C}$ mutations related to hypertrophic cardiomyopathy." $\underline{\mathrm{J} \text { Biol Chem }}$ 284(28): 19090-19100.

Potter, J. D. and J. Gergely (1975). "The calcium and magnesium binding sites on troponin and their role in the regulation of myofibrillar adenosine triphosphatase." Journal of Biological Chemistry 250(12): 4628-4633.

Potter, J. D., S. P. Robertson and J. D. Johnson (1981). "Magnesium and the regulation of muscle contraction." Fed Proc 40(12): 2653-2656.

Ramos, C. H. (1999). "Mapping subdomains in the C-terminal region of troponin I involved in its binding to troponin $\mathrm{C}$ and to thin filament." $\mathrm{J}$ Biol Chem 274(26): 18189-18195.

Reid, R. E. and R. M. Procyshyn (1995). "Engineering magnesium selectivity in the helix-loop-helix calcium-binding motif." Arch Biochem Biophys 323(1): 115-119.

Robertson, S., J. D. Johnson and J. Potter (1981). "The time-course of Ca2+ exchange with calmodulin, troponin, parvalbumin, and myosin in response to transient increases in Ca2+." Biophysical journal 34(3): 559.

Rocklin, G. J., D. L. Mobley, K. A. Dill and P. H. Hunenberger (2013). "Calculating the binding free energies of charged species based on explicit-solvent simulations employing lattice-sum methods: an accurate correction scheme for electrostatic finite-size effects." J Chem Phys 139(18): 184103.

Romani, A. and A. Scarpa (1992). "Regulation of cell magnesium." Arch Biochem Biophys 298(1): 1-12.

Romani, A. M. P. (2011). Intracellular magnesium homeostasis. Magnesium in the Central Nervous System. R. Vink and M. Nechifor. Adelaide (AU), University of Adelaide Press

(c) 2011 The Authors.

Sacco, C., R. A. Skowronsky, S. Gade, J. M. Kenney and A. M. Spuches (2012). "Calorimetric investigation of copper(II) binding to Abeta peptides: thermodynamics of coordination plasticity." J Biol Inorg Chem 17(4): 531-541.

Schober, T., S. Huke, R. Venkataraman, O. Gryshchenko, D. Kryshtal, H. S. Hwang, F. J. Baudenbacher and B. C. Knollmann (2012). "Myofilament Ca sensitization increases cytosolic Ca binding affinity, 
alters intracellular $\mathrm{Ca}$ homeostasis, and causes pause-dependent Ca-triggered arrhythmia." Circulation research 111(2): 170-179.

Seamon, K. B., D. J. Hartshorne and A. A. Bothner-By (1977). "Ca2+ and Mg2+ dependent conformations of troponin $\mathrm{C}$ as determined by $1 \mathrm{H}$ and $19 \mathrm{~F}$ nuclear magnetic resonance." Biochemistry 16(18): 4039-4046.

She, M., W. J. Dong, P. K. Umeda and H. C. Cheung (1998). "Tryptophan mutants of troponin C from skeletal muscle: an optical probe of the regulatory domain." European journal of biochemistry 252(3): 600-607.

Sia, S. K., M. X. Li, L. Spyracopoulos, S. M. Gagné, W. Liu, J. A. Putkey and B. D. Sykes (1997). "Structure of cardiac muscle troponin $\mathrm{C}$ unexpectedly reveals a closed regulatory domain." Journal of Biological Chemistry 272(29): 18216-18221.

Siddiqui, J. K., S. B. Tikunova, S. D. Walton, B. Liu, M. Meyer, P. P. de Tombe, N. Neilson, P. M. Kekenes-Huskey, H. E. Salhi, P. M. Janssen, B. J. Biesiadecki and J. P. Davis (2016). "Myofilament Calcium Sensitivity: Consequences of the Effective Concentration of Troponin I." Front Physiol 7: 632.

Skowronsky, R. A., M. Schroeter, T. Baxley, Y. Li, J. M. Chalovich and A. M. Spuches (2013). "Thermodynamics and molecular dynamics simulations of calcium binding to the regulatory site of human cardiac troponin $\mathrm{C}$ : evidence for communication with the structural calcium binding sites." JBIC Journal of Biological Inorganic Chemistry 18(1): 49-58.

Slupsky, C. M. and B. D. Sykes (1995). "NMR solution structure of calcium-saturated skeletal muscle troponin C." Biochemistry 34(49): 15953-15964.

Solaro, R. J. and J. S. Shiner (1976). "Modulation of Ca2+ control of dog and rabbit cardiac myofibrils by Mg2+. Comparison with rabbit skeletal myofibrils." Circ Res 39(1): 8-14.

Spyracopoulos, L., M. X. Li, S. K. Sia, S. M. Gagné, M. Chandra, R. J. Solaro and B. D. Sykes (1997). "Calcium-induced structural transition in the regulatory domain of human cardiac troponin C." Biochemistry 36(40): 12138-12146.

Steinbrecher, T., I. Joung and D. A. Case (2011). "Soft-core potentials in thermodynamic integration: comparing one- and two-step transformations." J Comput Chem 32(15): 3253-3263.

Stephenson, D. G. and D. A. Williams (1982). "Effects of sarcomere length on the force-pCa relation in fast- and slow-twitch skinned muscle fibres from the rat." J Physiol 333: 637-653.

Stevens, C. M., K. Rayani, C. E. Genge, G. Singh, B. Liang, J. M. Roller, C. Li, A. Y. Li, D. P. Tieleman and F. van Petegem (2016). "Characterization of Zebrafish Cardiac and Slow Skeletal Troponin C Paralogs by MD Simulation and ITC." Biophysical Journal 111(1): 38-49.

Stevens, C. M., K. Rayani, G. Singh, B. Lotfalisalmasi, D. P. Tieleman and G. F. Tibbits (2017). "Changes in the dynamics of the cardiac troponin $\mathrm{C}$ molecule explain the effects of Ca2+sensitizing mutations." Journal of Biological Chemistry 292(28): 11915-11926.

Strynadka, N. C. and M. N. James (1989). "Crystal structures of the helix-loop-helix calcium-binding proteins." Annu Rev Biochem 58: 951-998.

Sturtevant, J. M. (1977). "Heat capacity and entropy changes in processes involving proteins." Proc Natl Acad Sci U S A 74(6): 2236-2240.

Sundaralingam, M., R. Bergstrom, G. Strasburg, S. T. Rao, P. Roychowdhury, M. Greaser and B. C. Wang (1985). "Molecular structure of troponin C from chicken skeletal muscle at 3-angstrom resolution." Science 227(4689): 945-948. 
Tanaka, H., H. Takahashi and T. Ojima (2013). "Ca(2)+-binding properties and regulatory roles of lobster troponin C sites II and IV." FEBS Lett 587(16): 2612-2616.

Tessman, P. A. and A. Romani (1998). "Acute effect of $\mathrm{EtOH}$ on $\mathrm{Mg} 2+$ homeostasis in liver cells: evidence for the activation of an Na+/Mg2+ exchanger." Am J Physiol 275(5): G1106-1116.

Tikunova, S. B., D. J. Black, J. D. Johnson and J. P. Davis (2001). "Modifying Mg2+ binding and exchange with the N-terminal of calmodulin." Biochemistry 40(11): 3348-3353.

Tikunova, S. B. and J. P. Davis (2004). "Designing calcium-sensitizing mutations in the regulatory domain of cardiac troponin C." Journal of Biological Chemistry 279(34): 35341-35352.

van Eerd, J. P. and K. Takahshi (1976). "Determination of the complete amino acid sequence of bovine cardiac troponin C." Biochemistry 15(5): 1171-1180.

Vormann, J. and T. Günther (1987). "Amiloride-sensitive net Mg2+ efflux from isolated perfused rat hearts." Magnesium 6(4): 220-224.

Wang, K., M. Brohus, C. Holt, M. T. Overgaard, R. Wimmer and F. Van Petegem (2020). "Arrhythmia mutations in calmodulin can disrupt cooperativity of $\mathrm{Ca} 2+$ binding and cause misfolding." The Journal of Physiology 598(6): 1169-1186.

Wang, S.-Q., Y.-H. Huang, K.-S. Liu and Z.-Q. Zhou (1997). "Dependence of myocardial hypothermia tolerance on sources of activator calcium." Cryobiology 35(3): 193-200.

Wilcox, D. E. (2008). "Isothermal titration calorimetry of metal ions binding to proteins: An overview of recent studies." Inorganica Chimica Acta 361(4): 857-867.

Wnuk, W., M. Schoechlin and E. A. Stein (1984). "Regulation of actomyosin ATPase by a single calciumbinding site on troponin C from crayfish." J Biol Chem 259(14): 9017-9023.

Wolf, F. I., A. Di Francesco, V. Covacci, D. Corda and A. Cittadini (1996). "Regulation of intracellular magnesium in ascites cells: Involvement of different regulatory pathways." Archives of biochemistry and biophysics 331(2): 194-200.

Yamada, K. (1978). "The enthalpy titration of troponin C with calcium." Biochimica et Biophysica Acta (BBA)-Protein Structure 535(2): 342-347.

Yamada, K. (2003). "Calcium binding to troponin C as a primary step of the regulation of contraction. A microcalorimetric approach." Adv Exp Med Biol 538: 203-212; discussion 213.

Yamada, K. and K. Kometani (1982). "The changes in heat capacity and entropy of troponin C induced by calcium binding." The Journal of Biochemistry 92(5): 1505-1517.

Yap, K. L., J. B. Ames, M. B. Swindells and M. Ikura (1999). "Diversity of conformational states and changes within the EF-hand protein superfamily." Proteins 37(3): 499-507.

Yumoto, F., M. Nara, H. Kagi, W. Iwasaki, T. Ojima, K. Nishita, K. Nagata and M. Tanokura (2001). "Coordination structures of $\mathrm{Ca} 2+$ and $\mathrm{Mg} 2+$ in Akazara scallop troponin $\mathrm{C}$ in solution. FTIR spectroscopy of side-chain COO- groups." Eur J Biochem 268(23): 6284-6290.

Zot, A. S. and J. D. Potter (1987). "Structural aspects of troponin-tropomyosin regulation of skeletal muscle contraction." Annual review of biophysics and biophysical chemistry 16(1): 535-559. 
bioRxiv preprint doi: https://doi.org/10.1101/2020.06.14.150854; this version posted June 15, 2020. The copyright holder for this preprint (which was not certified by peer review) is the author/funder. All rights reserved. No reuse allowed without permission. 